\title{
Sex-specific risk of cardiovascular disease and cognitive decline: pregnancy and menopause
}

\author{
Virginia M Miller ${ }^{1 *}$, Vesna D Garovic ${ }^{2}$, Kejal Kantarci $^{3}$, Jill N Barnes ${ }^{4}$, Muthuvel Jayachandrann ${ }^{5}$, Michelle M Mielke ${ }^{6}$, \\ Michael J Joyner ${ }^{4}$, Lynne T Shuster ${ }^{7}$ and Walter A Rocca ${ }^{8}$
}

\begin{abstract}
Understanding the biology of sex differences is integral to personalized medicine. Cardiovascular disease and cognitive decline are two related conditions, with distinct sex differences in morbidity and clinical manifestations, response to treatments, and mortality. Although mortality from all-cause cardiovascular diseases has declined in women over the past five years, due in part to increased educational campaigns regarding the recognition of symptoms and application of treatment guidelines, the mortality in women still exceeds that of men. The physiological basis for these differences requires further research, with particular attention to two physiological conditions which are unique to women and associated with hormonal changes: pregnancy and menopause. Both conditions have the potential to impact life-long cardiovascular risk, including cerebrovascular function and cognition in women. This review draws on epidemiological, translational, clinical, and basic science studies to assess the impact of hypertensive pregnancy disorders on cardiovascular disease and cognitive function later in life, and examines the effects of post-menopausal hormone treatments on cardiovascular risk and cognition in midlife women. We suggest that hypertensive pregnancy disorders and menopause activate vascular components, i.e., vascular endothelium and blood elements, including platelets and leukocytes, to release cell-membrane derived microvesicles that are potential mediators of changes in cerebral blood flow, and may ultimately affect cognition in women as they age. Research into specific sex differences for these disease processes with attention to an individual's sex chromosomal complement and hormonal status is important and timely.
\end{abstract}

Keywords: Brain imaging, Cerebral blood flow, Cognition, Estrogen, Hormone, Hypertension, Microvesicles, Preeclampsia, White matter hyperintensities

\section{Review Introduction}

Sex differences from a medical perspective may include: 1 ) diseases/conditions specific to one sex, 2) diseases/conditions that disproportionately affect one sex, and 3) diseases/ conditions having distinctly different causes, manifestations, outcomes (morbidity or mortality), or treatments depending on sex. In this context, sex is defined by the sex chromosomal complement and the presence of reproductive organs [1]. Cardiovascular disease and cognitive decline are two potentially related conditions which fall into the second and third categories. For example, the development of cardiovascular disease, including hypertension, occurs

\footnotetext{
*Correspondence: miller.virginia@mayo.edu

'Departments of Surgery and Physiology and Biomedical Engineering, 200 1st St SW, Rochester, MN 55905, USA

Full list of author information is available at the end of the article
}

about 10 years earlier in men than in women, but it increases exponentially in women after menopause [2]. Conventional treatments for hypertension reduce blood pressure in both men and women, but these treatments are less likely to result in normotensive levels in women [3], suggesting that there are sex differences underlying these pathophysiologic processes [4-6].

Sex differences in autonomic function related to sympathetic control of the vascular resistance, and to the synthesis, uptake, and disposition of adrenergic neurotransmitters may explain the greater incidence of hypertension in men and the greater incidence of vasospastic diseases, such as migraine, Raynaud's disease, and postural orthostatic tachycardia syndrome (POTS) in women [7]. In addition, sex differences in the composition of the vascular and cardiac extracellular matrix contribute to the greater incidence of diastolic heart failure (heart failure with preserved ejection

\section{Biomed Central}


fraction, HFpEF) and transient apical ballooning syndrome (Takotsubo cardiomyopathy) in women compared to men [8-10].

Cognitive health following a cerebrovascular event also shows sex differences. For example, post-stroke disability [11], stroke-associated cognitive impairment [12] and dementia [13] are greater in women than in men. By 2050, the prevalence of Alzheimer's disease is estimated to reach 11-16 million in the United States [14,15]. The social and economic implications of this epidemic will be greatest in women because of their longer life expectancy and greater risk of dementia compared with men.

The physiological basis for these differences requires further research. Two conditions unique to women, pregnancy and menopause, which involve major hormonal changes, may contribute to distinct sex differences in morbidity, clinical manifestations, response to treatments, and mortality of cardiovascular disease and cognitive decline. This review examines the evidence suggesting that hypertensive pregnancy disorders, in particular, preeclampsia, affect cardiovascular risk in women as they age. In addition, it examines the evidence that menopausal hormone therapy (MHT) given close to the time of menopause reduces the risk for cardiovascular disease and cognitive decline. We will discuss the possible role of cell membrane-derived microvesicles in the blood that may affect endothelial function and sex-specific differences in the regulation of cerebral blood flow, as potential mechanisms mediating changes in cognition (Figure 1).

\section{Sex differences in cardiovascular pathophysiology}

Mechanisms involved in vascular and cardiac control and remodeling are regulated in part by sex steroid hormones. These mechanisms include the synthesis and degradation of norepinephrine [16,17], the expression of adrenergic receptors on vascular smooth muscle [18-22], the regulation of ion fluxes in cardiac and vascular smooth muscle [23-30], the production of endothelium-derived vasoactive factors [31,32] which affect total peripheral resistance (Figure 2, [33-37]), and cerebral blood flow [38-40]. Furthermore, regulation of extracellular collagen and elastin [41], and cellular apoptosis [42-46] may affect vascular and cardiac stiffness and remodeling processes that influence the development of vascular lesions and cardiac myopathies.

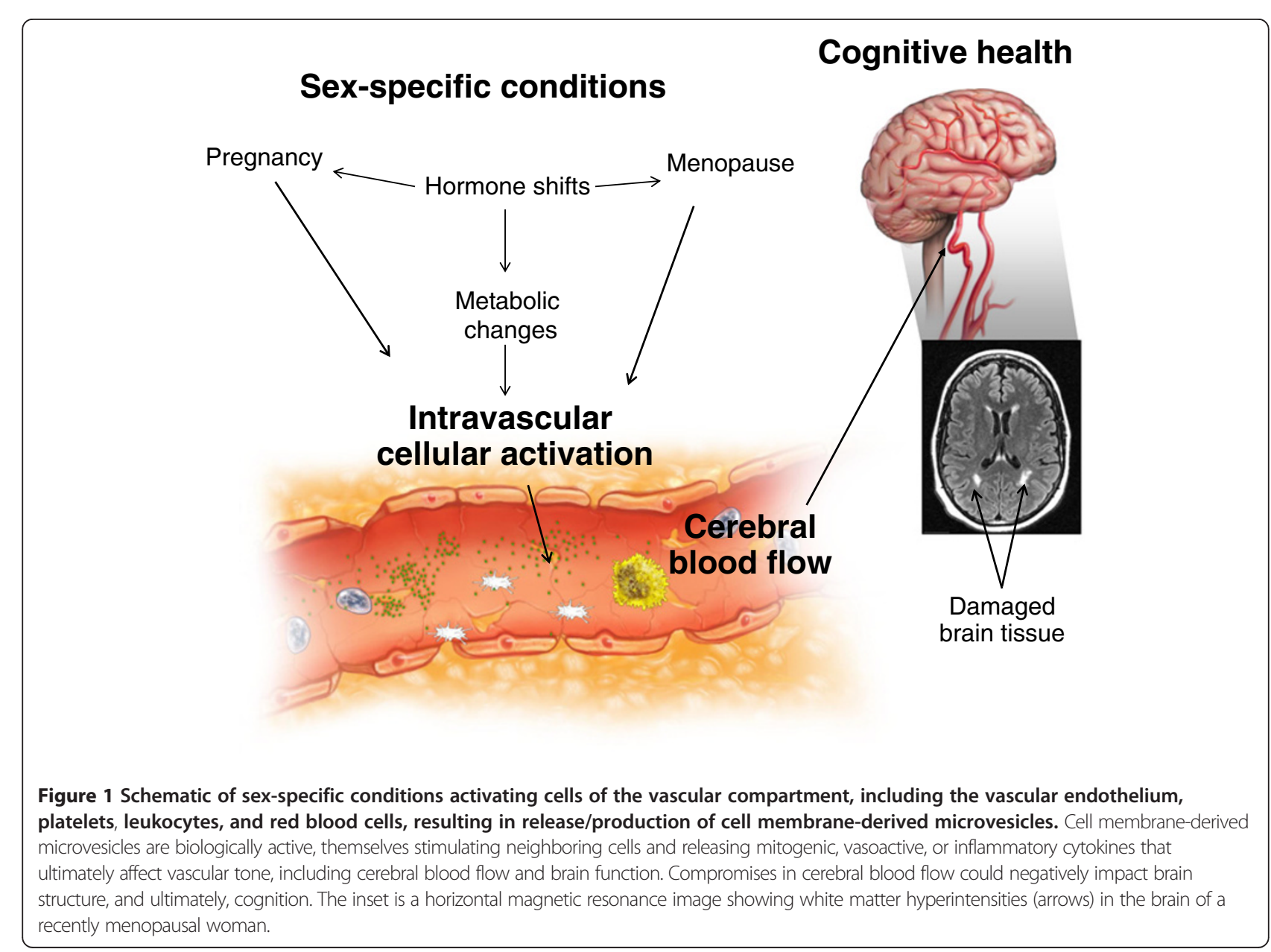



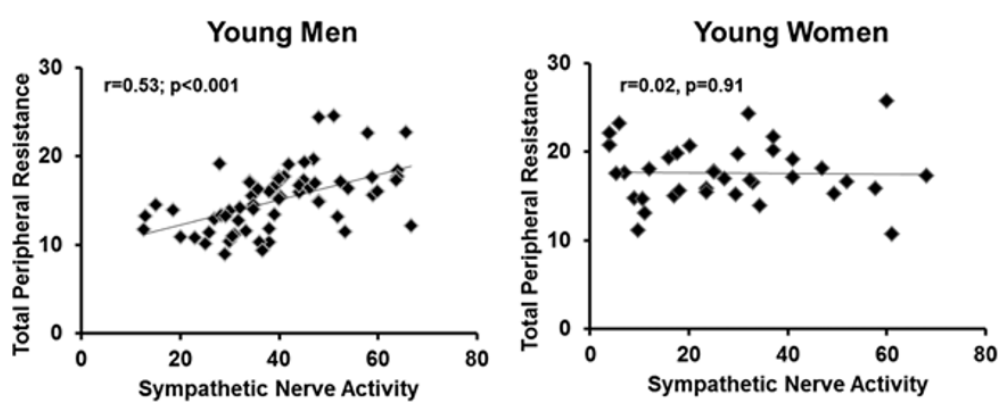

Figure 2 The association between sympathetic nerve activity and total peripheral resistance in young men $(n=63$; left panel) compared to young women $(\mathbf{n}=\mathbf{3 7}$; right panel). Data are combined from a series of studies investigating blood pressure regulation in healthy adults [33-36]. Each diamond represents an individual. Measurements of nerve activity were obtained using microneurography of the peroneal nerve under the same experimental conditions [37]. To control for fluctuations in sex hormones, women were studied only during the early follicular phase of the menstrual cycle.

Thus, we suggest that two sex-specific conditions associated with major hormonal changes in women, specifically hypertensive pregnancy disorders and menopause, contribute to the development of cardiovascular disease, including hypertension and hypertension-related disorders, that impact brain structure and function.

\section{Pregnancy-associated hypertension}

Hypertensive pregnancy disorders cover a spectrum of conditions, including preeclampsia, gestational hypertension, chronic hypertension, and preeclampsia superimposed on chronic hypertension. Preeclampsia, unlike other hypertensive disorders of pregnancy, is associated with proteinuria (Figure 3) [47].

The National High Blood Pressure Education Program Working Group Report on High Blood Pressure in Pregnancy indicated that hypertensive disorders occur in $6 \%$ to $8 \%$ of pregnancies [47]. However, population-based studies evaluating the incidence of these disorders have not yet been conducted [48]. Consequently, available studies significantly differ in reporting their frequencies: $7 \%$ to $22 \%$ for hypertension in pregnancy, in general $[49,50]$, and $1 \%$ to $8 \%$ for preeclampsia, in particular $[49,51,52]$. These differences result from lack of uniformity in defining the study populations and the clinical definitions of the disorders. In addition, the observed variations may have been further amplified by inaccuracies of diagnoses and differences in reporting chronic hypertension, which may predate pregnancy (chronic, prevalent hypertension), or occur for the first time during pregnancy and persist thereafter (chronic, incident hypertension) (Figure 3).

In addition to the short-term cardiovascular complications of preeclampsia (i.e., within three months postpartum), preeclampsia is associated with an increased risk of cardiovascular disease several years after the exposure. Two common study designs have been utilized to examine this long-term relationship. Case-control studies have examined women with cardiovascular events (e.g., myocardial

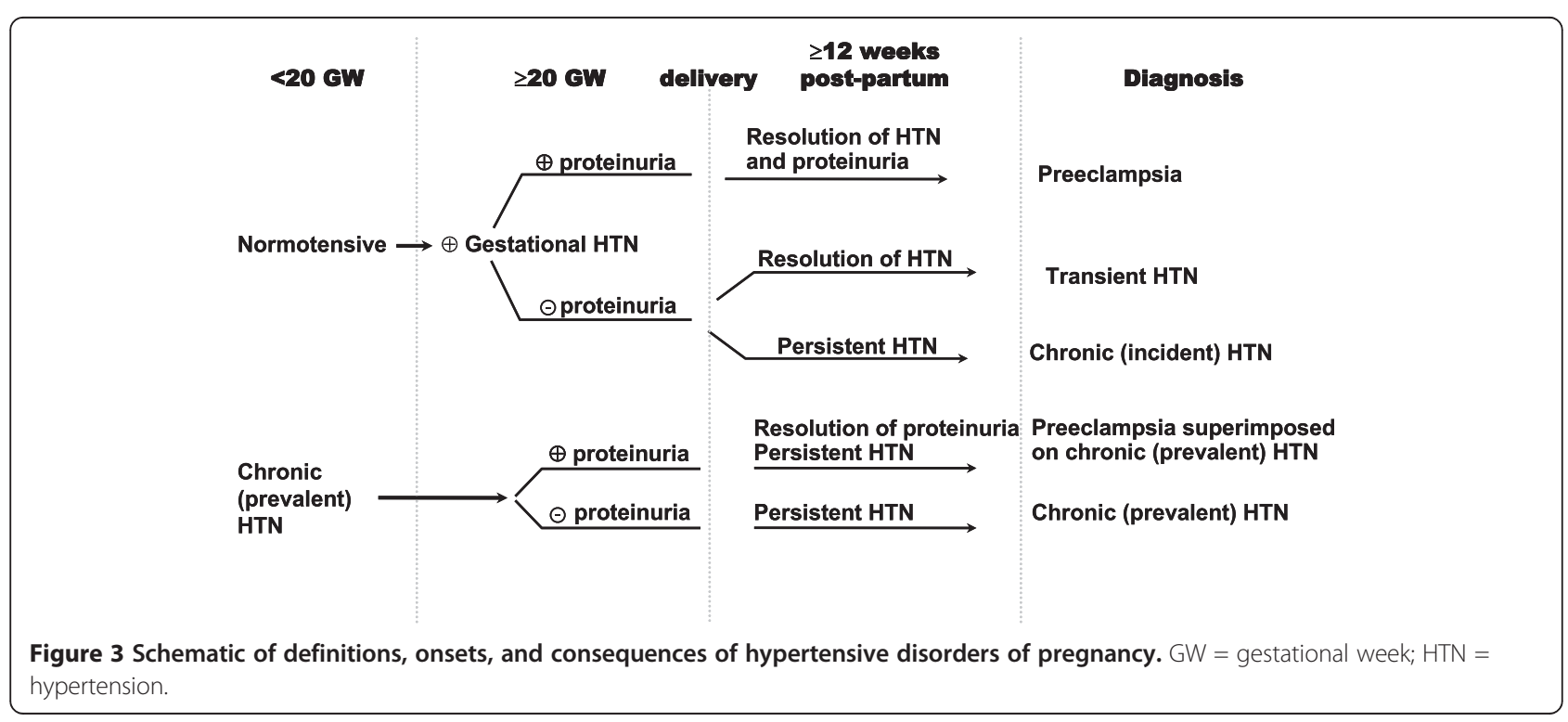


infarction, venous thromboembolism, and stroke) and compared their pregnancy histories with those of event-free women of similar age (controls). These studies have suggested that, compared with women without cardiovascular events, women with cardiovascular events were more likely to have experienced a preeclamptic or hypertensive pregnancy disorder [53-56].

Registry-based cohort studies also suggest that hypertensive pregnancy disorders are associated with an increased risk of cardiovascular events [57-63] and mortality [60,63-67]. It is important to note that these studies have not fully adjusted for traditional cardiovascular risk factors. Without adjustment for these factors, it is not possible to determine whether the association between hypertensive pregnancy disorders and vascular outcomes is or is not related to traditional vascular risk factors (e.g., hypertension, family history, hyperlipidemia, smoking, and diabetes mellitus). Other limitations of the published studies include that they are often registry based (selected clinical series), have reported a limited number of outcomes (such as cardiovascular deaths), and have not assessed the impact of a hypertensive pregnancy disorder on age of onset of the cardiovascular event. This information may be clinically useful when individualizing risk profiles and intervention strategies for women with a hypertensive pregnancy disorder. Further, the diagnoses of preeclampsia and other hypertensive pregnancy disorders typically have been ascertained using codes from administrative data sources or selfreported events, rather than using accepted diagnostic criteria $[58,61-63,68]$. The four major studies that did confirm the diagnosis of preeclampsia using accepted clinical criteria included only mortality outcomes, and not the incidence or prevalence of cardiovascular events (cardiovascular morbidity) [64-67].

Major differences in the clinical presentations of preeclampsia and other hypertensive pregnancy disorders probably result from differences in their underlying pathophysiological mechanisms, which might have varying implications for cardiovascular disease later in life. However, the mechanisms underlying these associations are poorly understood. Some risk factors, such as diabetes and obesity, may predispose women to hypertensive pregnancy disorders and preeclampsia at younger ages, and independently they may predispose women to cardiovascular complications and cognitive decline at different times in a women's life. In this situation, the pregnancy disorders have no causal relation to the later cardiovascular disease or cognitive decline. Alternatively, preeclampsia itself might induce irreversible vascular and metabolic changes that may increase the overall risk for cardiovascular disease (Figure 4). In this situation, the pregnancy disorders have a direct causal effect on vascular and cognitive outcomes.

In support of a direct causal effect, some studies showed that, despite normalization of blood pressure postpartum, these seemingly healthy women may demonstrate unfavorable metabolic and vascular changes [69], such as an impaired brachial artery flow-mediated (endothelium-dependent) dilatation, a measure of endothelial dysfunction, three years after the diagnosis of preeclampsia [70]. Also, micro-albuminuria, which may be a marker of endothelial dysfunction and/or renal injury, has been reported to be more prevalent following a preeclamptic pregnancy [71]. Echocardiographic studies showed an increased risk of concentric remodeling, eccentric hypertrophy, and impaired left ventricular relaxation one year postpartum in women with preeclamptic pregnancy compared with women with normotensive pregnancy [72].

Clarification of the mechanisms that underlie the association between hypertensive pregnancy disorders and future cardiovascular disease is important to establish more specific clinical guidelines for screening and/or treatment of cardiovascular disease in women. Current clinical guidelines recommend referral of women with a history of hypertensive pregnancy to primary care or cardiology in order to facilitate monitoring and control of cardiovascular risk factors, but there are no specific guidelines for management of these women [3].

\section{Menopause}

The risk of developing hypertension, ischemic heart disease, myocardial infarction and stroke increases in women after the onset of menopause, whether natural or surgically induced $[2,73]$. Estrogen-based treatments reduced the development of vascular lesions in experimental animals after oophorectomy [74-76]. Human studies have confirmed a reduced incidence of cardiovascular events and mortality in women using MHT for relief of menopausal symptoms after undergoing either surgical or natural menopause [73,77-85]. However, the timing of the initiation of such treatments is critical. Initiation of the treatment close to the time of menopause (i.e. within about 3 years) is more effective than delays in treatment of up to 5 years. This time period may represent a "window of opportunity" within which estrogenic treatments might be effective in reducing cardiovascular disease and associated events [86-88]. However, the impact of MHT on the development of hypertension at menopause remains controversial [89-92].

\section{Sex differences, hypertension, and cognitive aging}

Compared with men, women are at increased risk for Alzheimer's disease, the most common form of dementia [93-96], and their cognitive performance declines faster after the diagnosis of Alzheimer's disease [97,98]. There also appears to be a sex-specific pharmacological effect of drugs targeting acetylcholinesterase activity [99]. Indeed, in experimental animals, sex differences have been found for nearly all cholinergic markers, including 

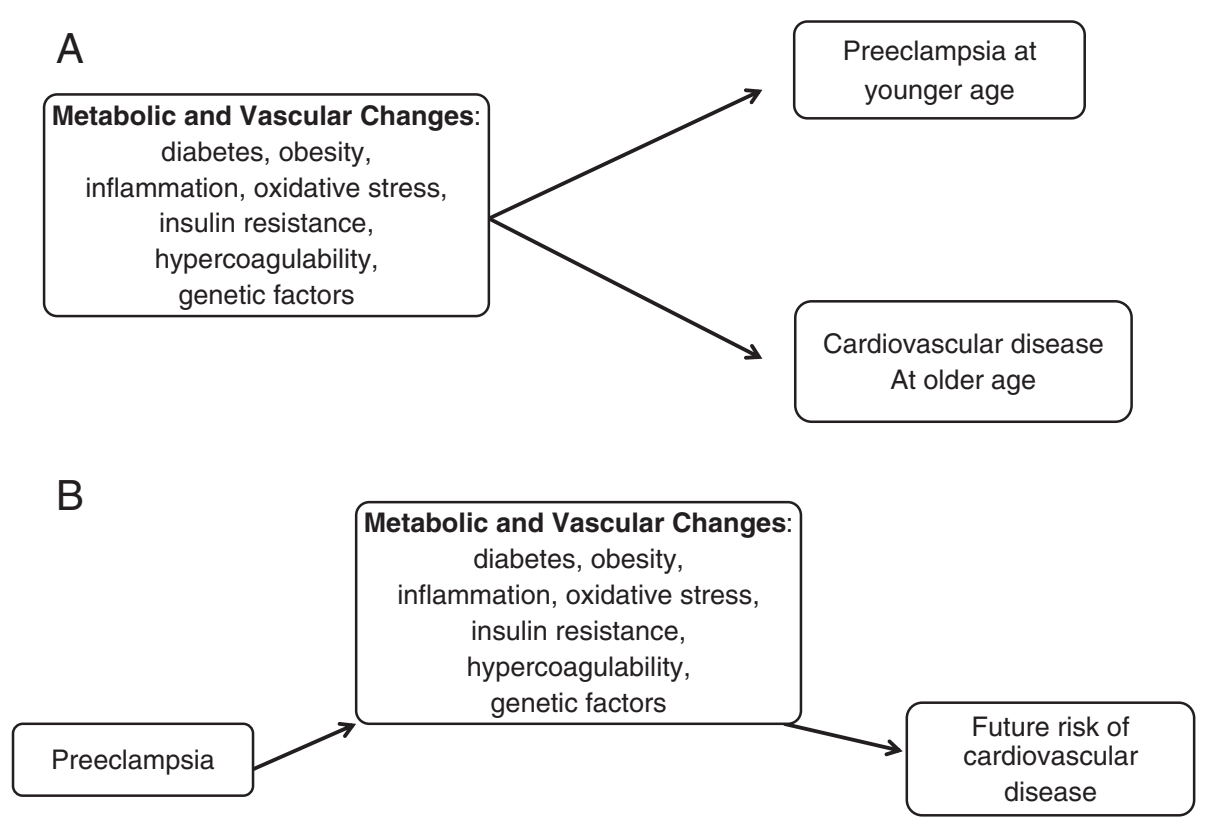

Figure 4 Schematic representation of interactions among factors contributing to the development of preeclampsia and cardiovascular risk in women as they age. Some risk factors, such as diabetes and obesity, may predispose women to hypertensive pregnancy disorders and preeclampsia at younger ages, and independently they may predispose women to cardiovascular complications and cognitive decline at older ages (A). Alternatively, preeclampsia itself might have direct causal effect (B) on vascular outcomes by inducing irreversible vascular and metabolic changes that may increase the overall risk for cardiovascular disease.

acetylcholinesterase activity, acetylcholine and acetylcholine receptor distribution [100-102]. These differences are likely related to sex hormones. Testosterone may interfere with the effects of cholinesterase inhibitors by decreasing the amount of drug that reaches the brain or by modifying the interaction of the cholinesterase inhibitor with cholinesterase $[103,104]$. However, reasons for these sex differences in the risk, progression, and treatment of dementia are not well understood.

Starting with Alois Alzheimer's initial findings in the brain of a woman, changes in the microvessels have been repeatedly reported in the brain of patients with Alzheimer's disease. These changes are now known to include cerebral amyloid angiopathy [105], endothelial degeneration [106], and vascular basement membrane alterations [107]. The notion that vascular factors are independent risk factors for Alzheimer's disease was initially controversial. Vascular factors are the primary cause of vascular dementia, and one hypothesis was that such factors would only be associated with mixed cases of Alzheimer's disease and vascular dementia. Additionally, it had been suggested that cardiovascular factors may be a consequence of Alzheimer's disease, rather than a cause. However, in the early 1990's, two publications reported an increased prevalence of senile plaques in patients with coronary artery disease $[108,109]$, thus linking cardiovascular disease to Alzheimer's disease. Since then, a number of epidemiological studies have confirmed that vascular- related conditions, such as hypertension [109,110], atherosclerosis [111], atrial fibrillation [112], diabetes [113,114], obesity [115], and stroke [116] increase the risk of Alzheimer's disease. Vascular factors also affect the rate of progression after a diagnosis of Alzheimer's disease [117]. Thus, vascular dementia and Alzheimer's disease are no longer thought of as distinct entities, but as overlapping diseases.

It is possible that women with a history of hypertensive pregnancy disorders also have an increased risk of dementia through their increased risk for cardiovascular disease and Alzheimer's disease later in life. This association is supported by the presence of white matter lesions, which appear on magnetic resonance imaging (MRI) as white matter hyperintensities (Figure 1) in women with severe forms of preeclampsia $[118,119]$. White matter hyperintensities are a recognized risk factor for both vascular dementia and Alzheimer's disease [120,121]. Much remains to be learned regarding the factors contributing to their development, or to their causal relationship to changes in cognitive function.

However, no study has directly examined hypertensive pregnancy disorders as a risk factor for subsequent cognitive impairment. Two studies have suggested that preeclampsia and eclampsia are associated with self-reported worsening of cognitive function [122] and memory performance [123], but they did not systematically examine the association between hypertensive pregnancy disorders and domain-specific cognitive functioning later in life. 
In women who develop eclampsia, a convulsive, severe form of hypertensive pregnancy disorder, the dilation of cerebral arteries is thought to result from a rapid increase in blood pressure, with resulting neurologic symptoms resembling those of a hypertensive encephalopathy [50]. With resolution of the hypertension, neurologic symptoms also resolve. However, the long-term consequences, for example, as women transition into menopause [49], on cerebral vascular function and residual effects on cognitive health remain unknown.

\section{Cerebral blood flow and neuronal function}

The brain does not have endogenous stores of energy. Therefore, brain metabolism depends on blood supplied by the cerebral circulation. In general, the dilatory capacity of the arterial vasculature, including that of the cerebral circulation, decreases with age [124-126]. This decrease is due, in part, to reduced production of endothelium-derived relaxing factors, such as nitric oxide, and increased production of endothelium-derived contracting factors, which may include cyclooxygenase products of arachidonic acid metabolism and superoxide radicals. These changes occur in the setting of decreased oxygen tension in the blood [38,124,127-129]. As sex-steroid hormones regulate many of these endothelium-derived relaxing and contracting factors [31,32], sex differences in the regulation of cerebral blood flow should be expected to manifest across the life span with changes in hormonal status.

One non-invasive method to measure vasodilator capacity of the cerebral arteries in humans is by transcranial Doppler during graded hypercapnia [130,131]. This technique has demonstrated that women have higher cerebral blood flow responses to hypercapnia compared with men of the same age, until the age of menopause [132]. However, this may be due, in part, to the higher baseline cerebral blood flow velocity in women of any age group. Although autoregulation should prevent changes in blood pressure from altering cerebral blood flow, emerging evidence suggests that sex differences in dynamic autoregulation exist [133]. Therefore, sex differences in "true" cerebral vasodilator capacity, when accounting for baseline flow velocity and acute changes in blood pressure, and their underlying mechanisms are unclear. Production of vasodilatory prostaglandins may be greater in women than in men, because the cyclooxygenase inhibitor indomethacin reduces the vasodilatory capacity to a greater extent in postmenopausal women than in age-matched men (Figure 5).

The vasodilatory capacity of the brachial artery decreases with preeclampsia [134] and menopause [135]. However, the effects of these conditions on the vasodilatory capacity of the cerebral circulation are unclear. For example, hypertensive pregnancy disorders, particularly preeclampsia, represent circumscribed events, and the future consequences of such events on cerebral vascular function have not been elucidated. In addition, although the risk of systemic hypertension increases at menopause, these effects of menopause on the cerebral circulation have not been defined. Furthermore, the effects of $\mathrm{MHT}$ on the cerebral circulation remain unclear [136-142].

Studies in experimental animals and cultured cells have consistently shown that estrogen enhances neurologic function and is neuroprotective, thus the maintenance of adequate estrogen levels could prevent or delay dementia in menopausal women. In observational studies comparing cognitive performance and dementia risk between a group of postmenopausal women who used MHT and a group of non-MHT users, MHT users performed better than nonusers on the Modified Mini-Mental State Examination, and on tests of verbal fluency, verbal memory, and verbal and spatial working memory [143-148]. However, other observational studies did not identify a difference in cognitive function and dementia risk between the MHT users and non-users [148-151].

As with cardiovascular disease, controversy exists regarding whether MHT can preserve neurologic function and decrease the risk of dementia when administered early in menopause (onset of treatment within 3-5 years). In the Women's Health Initiative Memory Study (WHIMS), dementia was not prevented in older women who initiated MHT later (after 5 years) into menopause [152,153]. However, several meta-analyses showed a $20 \%$ to $40 \%$ decrease in the risk of Alzheimer's disease for women who use MHT early in menopause [154-157], in observational studies. Unfortunately, observational studies are subject to confounding effects. For example, better educated and healthy women are more likely to be MHT users and more likely to be compliant than are less-educated and lesshealthy women (confounding by "healthy users" effect). Education and health are determinants of cognitive function by themselves, and these variables may not be fully adjusted during statistical analysis [152,158].

By contrast, randomized controlled clinical trials are not influenced by such confounding effects. Some randomized controlled trials have shown beneficial effects of MHT on cognition [159-161]. However, WHIMS, the largest randomized controlled trial designed to date to examine the effects of hormone therapy on cognitive function and incident dementia, found that conjugated estrogens, given to women at age 65 years and older (late into menopause), with or without medroxyprogesterone acetate, did not protect against dementia or cognitive decline. Rather, MHT substantially increased the risk of dementia and cognitive decline in these age groups [162-166].

It has been hypothesized that administration of estrogen during perimenopause, when endogenous estrogen concentrations are labile, protects against age-associated 
Control

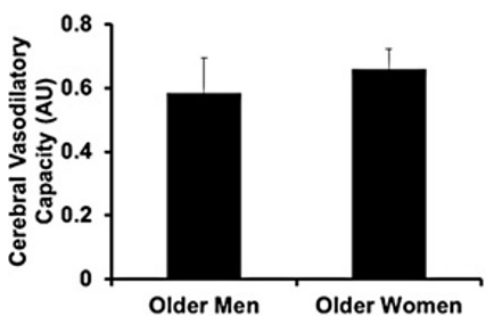

Cyclooxygenase Inhibition

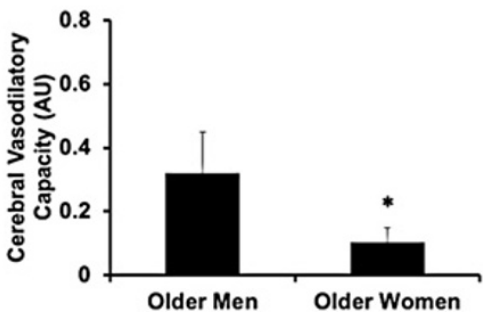

Figure 5 Sex differences in cerebral vasodilatory capacity, after accounting for baseline cerebral blood flow velocity and mean arterial pressure, in men and women between 55-75 years of age (average 65 years; unpublished data provided by Jill Barnes, an author of this review). The cerebrovascular responses to hypercapnia in age matched men $(n=6)$ and women $(n=6)$ are shown during control conditions (left panel) and during cyclooxygenase inhibition of vasodilating prostaglandins (right panel). Cyclooxygenase inhibition reduced the vasodilatory capacity (as area under the response curve, $\mathrm{AU}$ ) only in older women $\left({ }^{*} \mathrm{p}<0.05\right)$. Data are mean $\pm \mathrm{SE}$.

cognitive decline and dementia [167-173], but little is known about the mechanistic underpinnings of this hypothesis. In the rat hippocampus, aging leads to a loss of hippocampal estrogen receptor $\alpha$, estradiol sensitivity, and loss of estradiol-mediated neuroprotection against global cerebral ischemia. However, estradiol administration to middle-aged rats was neuroprotective, supporting the hypothesis of a "window of opportunity" or a critical period for the initiation of MHT [174].

Other mechanisms by which estrogen might provide neuronal protection, as suggested from studies of animals and cultured cells include: 1) improving synapse formation on hippocampal dendritic spines [175-177]; 2) increasing the activity of choline acetyltransferase in the basal forebrain and hippocampus (choline acetyltransferase is a synthetic enzyme for acetylcholine, a neurotransmitter implicated in memory function, that is markedly reduced in Alzheimer's disease) [178-181]; 3) reducing $\beta$-amyloid deposition in the brain and preventing the toxic effects of $\beta$-amyloid 1-42 on the neuronal mitochondria $[45,182,183]$; and 4) facilitating cerebral blood flow and acting as an antioxidant [40,184-186].

Following publication of clinical trial results from the WHIMS, there is a need for a randomized controlled trial to determine the neuroprotective effects of MHT in recently ( $<3$ years) postmenopausal women. However, determining these effects of MHT initiated close to menopause on the risk of dementia requires decades of follow-up, and is thus not feasible. A possible remedy to this obstacle is to use noninvasive imaging markers and measures of cerebral blood flow as short-term surrogate outcomes.

\section{Surrogate imaging markers for investigating cognitive health}

Volumetric MRI can be used to assess longitudinal effects of MHT on brain structure. Whole-brain and hippocampal volumes on MRI decrease during physiologic aging, accelerating after the fourth decade [187,188], with an annual rate of $0.2 \%$ decline in whole-brain volumes after age 54 years [189]. This decline in brain volume is consistent with autopsy studies showing that brain weight decreases after age 40 years. This decrease is thought to result from the degenerative processes of senescence such as cell shrinkage $[187,188]$. A direct relationship has been identified between hippocampal volumes on MRI and hippocampal neuronal density at autopsy in cognitively normal older adults and patients with Alzheimer's disease [190]. Although, volumetric MRI is regarded as a surrogate for the structural integrity of the neurons in the elderly [191], similar studies of hippocampal volume in women close to menopause or with a history of hypertensive pregnancy disorders, and obtained in conjunction with assessments of cognition are needed.

A quantitative MRI marker of cerebrovascular health is white matter hyperintensities associated with small-vessel vascular disease in the brain [192]. Hypertensive renal disease is strongly associated with white matter hyperintensities [193], and better control of blood pressure slows their progression $[194,195]$. There is an association between white matter hyperintensity load and future risk of mild cognitive impairment [196-198]. On average, white matter hyperintensities are more common in patients with mild cognitive impairment and Alzheimer's disease $[199,200]$, in agreement with autopsy studies in which vascular disease was more common in patients with Alzheimer's disease pathology [199,200]. Thus, quantitative analysis of the load of white matter hyperintensities may provide insight into the mechanisms by which menopause and hypertensive pregnancy disorders affect cognitive function in women.

Results of cross-sectional studies using MRI to assess the effects of MHT on brain morphology are mixed. One study found a decrease in gray matter volumes in MHT users compared to non-users [201], while another study found that MHT did not affect gray or white matter volumes 
[202]. Other studies found greater volumes of hippocampus [203-205], prefrontal cortex [206], cerebellum [203,207], temporal lobe gray matter $[203,206]$, parietal lobe gray matter [203,206,207] and white matter [208] in cognitively normal MHT users compared to non-users. Some of these regions of brain morphology are involved in memory function.

Contrary to the findings from observational studies, data from WHIMS indicate greater hippocampal atrophy in postmenopausal women who are treated with hormones at age 65 years and older [209] and a slightly greater increase in white matter hyperintensities [210]. In WHIMS, women with low baseline cognitive function and high ischemic white matter hyperintensities were more prone to this MHT effect on the hippocampus, suggesting greater vulnerability of an already compromised brain to hormone treatment [209,210]. Furthermore, hippocampal volumes correlated with cognitive function in the treated group, suggesting MHT induces cognitive impairment through increased brain atrophy [163]. White matter hyperintensities in WHIMS were associated with baseline blood pressure, and a greater longitudinal increase in white matter hyperintensities occurred in those with higher blood pressure, demonstrating longitudinal blood pressure effects [211]. MRI findings in WHIMS are consistent with the previously reported decline in cognitive function and an increased risk of dementia with hormone treatment, and demonstrate that MRI-based measures of brain morphology are useful surrogates of cognitive function in postmenopausal women [210].

Diffusion tensor imaging is gaining acceptance as the preferred quantitative imaging technique for assessing white matter integrity in the aging brain. Data from experimental models suggest that the directionality of diffusion along the axonal projections measured with fractional anisotropy decreases with the loss of myelin and axons [212,213]. The reduction in fractional anisotropy in the white matter has been associated with the ischemic white matter hyperintensities in cognitively healthy elderly men and women. These fractional anisotropy reductions are not confined to hyperintense lesions but are also found in the normal appearing white matter $[214,215]$. One possible explanation for these diffusion abnormalities in the normal appearing white matter is that the decrease in fractional anisotropy may be antecedent to the white matter hyperintensities which are the end stage of ischemic vascular damage to the white matter [216]. The relationship between vascular risk factors and fractional anisotropy reduction in the white matter [215] further suggests that fractional anisotropy reduction in the aging brain may be a marker for subclinical cerebrovascular disease. Although the biological basis of diffusivity changes in the aging brain is yet unclear, the association between white matter fractional anisotropy and cognitive function underscores the potential of this new imaging technique [217-219].

Retention of the radio-labeled compound, Pittsburgh compound-B (PiB), monitored by positron emission tomography (PET) is a direct measure of the $\beta$-amyloid deposits in Alzheimer's disease. A positive PET scan indicating the presence of $\beta$-amyloid deposits in cognitively normal adults is proposed as one of the research criteria for preclinical Alzheimer's disease [220]. PiB binds to both $\beta$-amyloid 1-40 and $\beta$-amyloid 1-42 peptide species. Because $\beta$-amyloid 140 is the major $\beta$-amyloid peptide species within blood vessels, $\mathrm{PiB}$ is also sensitive to the $\beta$-amyloid associated vasculopathy or cerebral amyloid angiopathy [221]. Retention of $\mathrm{PiB}$ increases with age, and high $\mathrm{PiB}$ retention (at levels found in Alzheimer's disease) was observed in 5.7\% of normal individuals between the ages of 50 to 59 years, and in $19.0 \%$ of individuals between the ages of 60 to 69 years [222]. In the population-based Mayo Clinic Study of Aging, high $\mathrm{PiB}$ retention was present in $33 \%$ of cognitively normal older adults (average age, 79 years) [223]. Although estrogen is thought to modify the risk of Alzheimer's disease, the effects of MHT on $\beta$-amyloid pathology need further investigation.

\section{Mediators of altered cerebral blood flow}

Changes in cerebral blood flow may affect brain function acutely, as might occur with stroke or a preeclamptic event, or chronically, as might occur during changes in hormonal status (pregnancy and menopause) or during sustained hypertension [211]. To link these blood flow events to altered cognition, we can hypothesize that activation of some components in the blood (i.e. soluble components such as hormones or cytokines and/or cellular blood elements, including cell membrane-derived microvesicles), may reduce cerebral circulation, ultimately causing structural changes to the brain followed by cognitive impairment (Figure 1). Although this hypothesis requires rigorous testing, several lines of evidence point to its plausibility.

Blood platelets alter arterial diameter through their interactions with the vascular endothelium and smooth muscle cells [224-226]. These interactions are modulated by sex-steroid hormones [227-229]. Indeed, the content of several classes of vasoactive and mitogenic agents in platelets-including nitric oxide, prostacyclin, thromboxane $A_{2}$, 5-hydroxytryptamine, tissue factor, tissue factor pathway inhibitor, transforming growth factor $\beta$, matrix metalloproteinases, and platelet-derived growth factors-varies with estrogen treatments [227,230-234].

Preeclampsia is characterized by a maternal hypercoagulable state, with increased intravascular coagulation and micro-thromboses that impair blood supply to several organs (Figure 4) [235-239]. Whether this hypercoagulable state or platelet activation contributes to overall 
cardiovascular risk or cerebrovascular vasodilatory capacity in women as they age remains to be determined.

Platelet activation may contribute to the progression of mild cognitive impairment or dementia. Significantly higher basal expressions of the platelet activation markers glycoprotein IIb/IIIa (PAC-1 binding) and P-selectin were observed in patients who developed cognitive decline at one year of follow-up (decrease of Mini-Mental State Examination score $>4$ ) compared with patients without decline (decrease in score $\leq 4$ ) [240]. Furthermore, platelets from patients with Alzheimer's disease and mild cognitive impairment contain higher concentrations of amyloid precursor protein and serotonin, and lesser amounts of epidermal growth factor and matrix metalloprotease-2 compared to healthy controls [241]. With ischemia, platelet aggregates accumulate both inside and outside of the blood-brain barrier and co-localize with toxic fragments of amyloid precursor protein. These observations suggest that progressive injury of brain parenchyma may be caused not only by degeneration of neurons destroyed during ischemia, but also by chronic damage to the bloodbrain barrier, with the accumulation of amyloid precursor protein in the perivascular space, thereby leading to Alzheimer's-disease pathology [242].

During cell-cell interactions, such as platelet interactions with other blood elements (i.e., leukocytes), cerebral vascular endothelium, or neurons, sealed membrane vesicles of $<1 \mu \mathrm{m}$ in diameter are shed into the circulation. Each microvesicle carries surface proteins/receptors characteristic of its cell of origin. Microvesicles are biochemically active and potentially important in several diseases, including cerebrovascular disease, preeclampsia, myeloproliferative disorders, and ischemic brain disease [243-247]. The composition of microvesicles and their numbers in the circulation depend on their cells of origin and the stimuli that trigger their production. Digital flow cytometry (FACSCanto ) and solid-phase fluorescence assays can be used to accurately identify and quantify the cellular origins of circulating microvesicles and their pathophysiologic characteristics $[246,248,249]$. Thus, it is possible to evaluate populations of circulating microvesicles, in early as well as late disease processes (e.g., development of white matter hyperintensities, $\beta$-amyloid pathology of Alzheimer's disease, structural MRI changes associated with neuronal degeneration), and to study their associations with the cognitive health of women who have experienced preeclampsia, menopause, or who have used MHT. For example, in a subgroup of the women enrolled in the Kronos Early Estrogen Prevention Study (KEEPS) [250], increases in white matter hyperintensities over a four year period correlated with the number of activated, plateletderived microvesicles at baseline [251].

These results suggest that blood borne microvesicles are part of a cascade of events that lead to the development of white matter hyperintensities. The effects of MHT on 1) the number and cellular origins of microvesicles, 2) the development of white matter hyperintensities, and 3) on direct measures of cerebral vasodilatory capacity remain to be determined. These studies can be extended to men in order to evaluate the association of testosterone deficiency with overall cardiovascular risk and cognitive decline.

\section{Conclusions}

Viewing research and delivery of medical care through a "sex-based lens," with attention to an individual's sex chromosomal complement and hormonal status, is fundamental to individualized medicine. Changes in cerebrovascular function and cognitive health in women affected by female-specific conditions, such as preeclampsia and menopause, remain unexplored or controversial. Interdisciplinary research teams using population-based epidemiologic methods, structural imaging, and functional physiological and biochemical approaches are positioned to address these important and timely research questions. The ultimate goal is to improve preventive, diagnostic, and treatment strategies that could reduce sex disparities in disease and improve the health for women and men throughout their life spans.

\section{Abbreviations \\ MHT: Menopausal hormone therapy; MRI: Magnetic resonance imaging; WHIMS: Women's health initiative memory study.}

\section{Competing interests}

None of the authors declare competing financial interests.

\section{Authors' contribution}

VMM, VDG, KK, JNB, MJ ,MMM, MJJ, LTS and WAR have contributed to the conception, drafting and editing of the manuscript. All authors read and approved the final manuscript.

\section{Acknowledgements}

This work was supported by grants from the NIA, AG 44170 and the Mayo Foundation. Mayo Clinic is a NIH designated Specialized Center on Research of Sex Differences.

\section{Author details}

${ }^{1}$ Departments of Surgery and Physiology and Biomedical Engineering, 200 1st St SW, Rochester, MN 55905, USA. ²Division of Nephrology and Hypertension, 200 1st St SW, Rochester, MN 55905, USA. ${ }^{3}$ Department of Radiology, 200 1st St SW, Rochester, MN 55905, USA. ${ }^{4}$ Department of Anesthesiology, 200 1st St SW, Rochester, MN 55905, USA. ${ }^{5}$ Department of Physiology and Biomedical Engineering, 200 1st St SW, Rochester, MN 55905, USA. ${ }^{6}$ Department of Health Science Research, Division of Epidemiology, 200 1st St SW, Rochester, MN 55905, USA. Department of Internal Medicine, Women's Health Clinic, 200 1st St SW, Rochester, MN 55905, USA.

${ }^{8}$ Department of Health Science Research, Division of Epidemiology, and Neurology, College of Medicine, Mayo Clinic, 200 1st St SW, Rochester, MN 55905, USA

Received: 21 December 2012 Accepted: 5 March 2013

Published: 28 March 2013

\section{References}

1. Sex CoUtBo, Differences G, Policy BoHS: Exploring the Biological Contributions to Human Health: Does Sex Matter?. Washington, DC: The National Academies Press; 2001 
2. Roger VL, Go AS, Lloyd-Jones DM, Benjamin EJ, Berry JD, Borden WB, Bravata DM, Dai S, Ford ES, Fox CS, et al: Heart disease and stroke statistics-2012 update: a report from the American heart association. Circulation 2012, 125(1):e2-e220.

3. Mosca L, Benjamin EJ, Berra K, Bezanson JL, Dolor RJ, Lloyd-Jones DM, Newby LK, Pina IL, Roger VL, Shaw LJ, et al: Effectiveness-based guidelines for the prevention of cardiovascular disease in women-2011 update: a guideline from the American heart association. Circulation 2011, 123(11):1243-1262.

4. Reckelhoff JF, Fortepiani LA: Novel mechanisms responsible for postmenopausal hypertension. Hypertension 2004, 43(5):918-923.

5. Narkiewicz K, Phillips BG, Kato M, Hering D, Bieniaszewski L, Somers VK. Gender-selective interaction between aging, blood pressure, and sympathetic nerve activity. Hypertension 2005, 45(4):522-525.

6. Hart EC, Charkoudian N, Wallin BG, Curry TB, Eisenach JH, Joyner MJ: Sex differences in sympathetic neural-hemodynamic balance: implications for human blood pressure regulation. Hypertension 2009, 53:571-576.

7. Hart EC, Charkoudian N, Miller VM: Sex, hormones and neuroeffector mechanisms. Acta Physiologica 2010, 203:155-165.

8. Regitz-Zagrosek V, Lehmkuhl E: Heart failure and its treatment in women. Role of hypertension, diabetes, and estrogen. Herz 2005, 30(5):356-367.

9. Arain FA, Kuniyoshi FH, Abdalrhim AD, Miller VM: Sex/gender medicine: the biological basis for personalized care in cardiovascular medicine. Circ $J$ 2009, 73(10):1774-1782.

10. Zakeri R, Vallejo-Giraldo C, Taylor KE, Miller VM, Schaible NS: Using heart failure with preserved ejection fraction to understand an 'omics approach to evaluating vascular dysfunction and cardiovascular disease. J Neurol Neurophysiol 2011:S1-006.

11. Petrea RE, Beiser AS, Seshadri S, Kelly-Hayes M, Kase CS, Wolf PA: Gender differences in stroke incidence and poststroke disability in the Framingham heart study. Stroke 2009, 40(4):1032-1037.

12. Gargano JW, Reeves MJ: Sex differences in stroke recovery and strokespecific quality of life: results from a statewide stroke registry. Stroke 2007, 38(9):2541-2548

13. Gall SL, Donnan G, Dewey HM, Macdonell R, Sturm J, Gilligan A, Srikanth V, Thrift AG: Sex differences in presentation, severity, and management of stroke in a population-based study. Neurology 2010, 74(12):975-981.

14. Alzheimer's Association: 2012 Alzheimer's disease facts and figures. Alzheimers Dement 2012, 8:131-168.

15. Herbert LE, Weuve J, Scherr PA, Evans DA: Alzheimer disease in the United States (2010-2050) estimated using the 2010 census. Neurology 2013. doi:10.1212/WNL.0b013e31828726f5

16. Sudhir K, Esler MD, Jennings GL, Komesaroff PA: Estrogen supplementation decreases norepinephrine-induced vasoconstriction and total body norepinephrine spillover in perimenopausal women. Hypertension 1997, 30:1538-1543

17. Herbison AE, Simonian SX, Thanky NR, Bicknell RJ: Oestrogen modulation of noradrenaline neurotransmission. Novartis Found Symp 2000, 230:74-85. discussion 85-93.

18. Anglin JC, Brooks VL: Tyrosine hydroxylase and norepinephrine transporter in sympathetic ganglia of female rats vary with reproductive state. Auton Neurosci 2003, 105:8-15.

19. Moldovanova I, Shroeder C, Jacob G, Hiemke C, Diedrich A, Luft J J FC: Hormonal influences on cardiovascular norepinephrine transporter responses in healthy women. Hypertension 2008, 51(4):1203-1209.

20. Paden CM, McEwen BS, Fishman J, Snyder L, DeGroff V: Competition by estrogens for catecholamine receptor binding in vitro. J Neurochem 1982, 39(2):512-520.

21. Lloyd T, Weisz J: Direct inhibition of tyrosine hydroxylase activity by catechol estrogens. J Biol Chem 1978, 253:4841-4843.

22. Ball $\mathrm{P}$, Knuppen $\mathrm{R}$, Haupt M, Breuer $\mathrm{H}$ : Interactions between estrogens and catechol amines. 3. Studies on the methylation of catechol estrogens, catechol amines and other catechols by the ctechol-O -methyltransferases of human liver. J Clin Endocrinol Metab 1972 34(4):736-746

23. Christian RC, Harrington S, Edwards WD, Oberg AL, Fitzpatrick LA: Estrogen status correlates with the calcium content of coronary atherosclerotic plaques in women. J Clin Endocrinol Metab 2002, 87:1062-1067.

24. Bupha-Intr T, Wattanapermpool J: Regulatory role of ovarian sex hormones in calcium uptake activity of cardiac sarcoplasmic reticulum. Am J Physiol Heart Circ Physiol 2006, 291(3):H1101-1108.
25. Cauley JA, Robbins J, Chen Z, Cummings SR, Jackson RD, LaCroix AZ, LeBoff M, Lewis CE, McGowan J, Neuner J, et al: Effects of estrogen plus progestin on risk of fracture and bone mineral density: the Women's Health Initiative randomized trial. JAMA 2003, 290(13):1729-1738.

26. Liu PY, Christian RC, Ruan M, Miller VM, Fitzpatrick LA: Correlating androgen and estrogen steroid receptor expression with coronary calcification and atherosclerosis in men without known coronary artery disease. J Clin Endocrinol Metab 2005, 90(2):1041-1046.

27. Vattikuti $R$, Towler DA: Osteogenic regulation of vascular calcification: an early perspective. Am J Physiol Endocrinol Metab 2004, 286(5):E686-E696.

28. Prakash YS, Togaibayeva AA, Kannan MS, Miller VM, Fitzpatrick LA, Sieck GC: Estrogen increases [Ca2+] efflux from female porcine coronary arterial smooth muscle. Am J Physiol Heart Circ Physiol 1999, 45:H926-H934.

29. White RE, Darkow DJ, Falvo Lang JL: Estrogen relaxes coronary arteries by opening BKCachannels through a cGMP-dependent mechanism. Circ Res 1995, 77:936-942.

30. Deenadayalu VP, White RE, Stallone JN, Gao X, Garcia AJ: Testosterone relaxes coronary arteries by opening the large-conductance, calciumactivated potassium channel. Am J Physiol Heart Circ Physiol 2001, 281: $\mathrm{H} 1720-\mathrm{H} 1727$.

31. Miller VM, Duckles SP: Vascular actions of estrogens: functional implications. Pharmacol Rev 2008, 60(2):210-241.

32. Duckles SP, Miller VM: Hormonal modulation of endothelial NO production. Pflugers Arch Eur J Physiol 2010, 459:841-851.

33. Charkoudian N, Joyner MJ, Barnes SA, Johnson CP, Eisenach JH, Dietz NM, Wallin BG: Relationship between muscle sympathetic nerve activity and systemic hemodynamics during nitric oxide synthase inhibition in humans. Am J Physiol Heart Circ Physiol 2006, 291(3):H1378-1383.

34. Charkoudian N, Joyner MJ, Sokolnicki LA, Johnson CP, Eisenach JH, Dietz NM, Curry TB, Wallin BG: Vascular adrenergic responsiveness is inversely related to tonic activity of sympathetic vasoconstrictor nerves in humans. J Physio/ 2006, 572(Pt 3):821-827.

35. Hart EC, Joyner MJ, Wallin BG, Johnson CP, Curry TB, Eisenach JH, Charkoudian N: Age-related differences in the sympathetic-hemodynamic balance in men. Hypertension 2009, 54(1):127-133.

36. Hart EC, Charkoudian N, Wallin BG, Curry TB, Eisenach J, Joyner MJ: Sex and ageing differences in resting arterial pressure regulation: the role of the beta-adrenergic receptors. J Physio/ 2011, 589(Pt 21):5285-5297.

37. Charkoudian N, Joyner MJ, Johnson CP, Eisenach JH, Dietz NM, Wallin BG: Balance between cardiac output and sympathetic nerve activity in resting humans: role in arterial pressure regulation. J Physiol 2005, 568:315-321.

38. Krause DN, Duckles SP, Pelligrino DA: Influence of sex steroid hormones on cerebrovascular function. J Appl Physiol 2006, 101(4):1252-1261.

39. Li W, Zheng T, Altura BM, Altura BT: Sex steroid hormones exert biphasic effects on cytosolic magnesium ions in cerebral vascular smooth muscle cells: possible relationships to migraine frequency in premenstrual syndromes and stroke incidence. Brain Res Bull 2001, 54(1):83-89.

40. Resnick SM, Maki PM, Golski S, Kraut MA, Zonderman AB: Effects of estrogen replacement therapy on PET cerebral blood flow and neuropsychological performance. Horm Behav 1998, 34(2):171-182.

41. Mahmoodzadeh S, Dworatzek E, Fritschka S, Pham TH, Regitz-Zagrosek V: 17Beta-estradiol inhibits matrix metalloproteinase-2 transcription via MAP kinase in fibroblasts. Cardiovasc Res 2010, 85(4):719-728.

42. Fliegner D, Schubert C, Penkalla A, Witt H, Kararigas G, Dworatzek E, Staub E, Martus $P$, Ruiz Noppinger $P$, Kintscher $U$, et al: Female sex and estrogen receptor-beta attenuate cardiac remodeling and apoptosis in pressure overload. Am J Physiol Regul Integr Comp Physiol 2010, 298(6):R1597-1606.

43. Spyridopoulos I, Sullivan AB, Kearney M, Isner JM, Losordo DW: Estrogenreceptor-mediated inhibition of human endothelial cell apoptosis. Estradiol as a survival factor. Circulation 1997, 95(6):1505-1514.

44. Yuan M, Siegel C, Zeng Z, Li J, Liu F, McCullough LD: Sex differences in the response to activation of the poly (ADP-ribose) polymerase pathway after experimental stroke. Exp Neurol 2009, 217(1):210-218.

45. Nilsen J, Chen S, Irwin RW, Iwamoto S, Brinton RD: Estrogen protects neuronal cells from amyloid beta-induced apoptosis via regulation of mitochondrial proteins and function. BMC Neurosci 2006, 7:74.

46. Wise PM, Dubal DB, Wilson ME, Rau SW, Liu Y: Estrogens: trophic and protective factors in the adult brain. Front Neuroendocrinol 2001, 22(1):33-66.

47. Report of the National High Blood Pressure Education Program Working Group on High Blood Pressure in Pregnancy. Am J Obstet Gynecol 2000, 183(1):S1-S22. 
48. ACGO Committee on Obstetric Practice: ACOG practice bulletin. Diagnosis and management of preeclampsia and eclampsia. Number 33, January 2002. American College of Obstetricians and Gynecologists. Int J Gynaecol Obstet 2002, 77(1):67-75

49. Saftlas AF, Olson DR, Franks AL, Atrash HK, Pokras R: Epidemiology of preeclampsia and eclampsia in the United States, 1979-1986. Am J Obstet Gynecol 1990, 163(2):460-465

50. Levine RJ, Hauth JC, Curet LB, Sibai BM, Catalano PM, Morris CD, DerSimonian R, Esterlitz JR, Raymond EG, Bild DE, et al: Trial of Calcium to Prevent Preeclampsia. N Engl J Med 1997, 337(2):69-77.

51. Kuklina EV, Ayala C, Callaghan WM: Hypertensive disorders and severe obstetric morbidity in the United States. Obstet Gynecol 2009, 113(6):1299-1306

52. Sibai BM, Caritis SN, Thom E, Klebanoff M, McNellis D, Rocco L, Paul RH, Romero R, Witter F, Rosen M, et al: Prevention of Preeclampsia with LowDose Aspirin in Healthy, Nulliparous Pregnant Women. N Engl J Med 1993, 329(17):1213-1218.

53. anonymous: Venous thromboembolic disease and combined oral contraceptives: results of international multicentre case-control study. World Health Organization Collaborative Study of Cardiovascular Disease and Steroid Hormone Contraception.[see comment]. Lancet 1995 346(8990):1575-1582.

54. anonymous: Haemorrhagic stroke, overall stroke risk, and combined oral contraceptives: results of an international, multicentre, case-control study. WHO Collaborative Study of Cardiovascular Disease and Steroid Hormone Contraception.[see comment]. Lancet 1996, 348(9026):505-510.

55. Croft $P$, Hannaford PC: Risk factors for acute myocardial infarction in women: evidence from the Royal College of General Practitioners' oral contraception study.[see comment]. BMJ 1989, 298(6667):165-168.

56. Mann Jl, Doll R, Thorogood M, Vessey MP, Waters WE: Risk factors for myocardial infarction in young women. Br J Prev Soc Med 1976, 30(2):94-100

57. Garovic VD, Bailey KR, Boerwinkle E, Hunt SC, Weder AB, Curb D, Mosley TH, Wiste HJ, Turner ST: Hypertension in pregnancy as a risk factor for cardiovascular disease later in life. J Hypertens 2010, 28:826-833.

58. Kestenbaum B, Seliger SL, Easterling TR, Gillen DL, Critchlow CW, StehmanBreen CO, Schwartz SM: Cardiovascular and thromboembolic events following hypertensive pregnancy. Am J Kidney Dis 2003, 42(5):982-989.

59. Hannaford P, Ferry S, Hirsch S: Cardiovascular sequelae of toxaemia of pregnancy. Heart 1997, 77(2):154-158.

60. Smith GC, Pell JP, Walsh D: Pregnancy complications and maternal risk of ischaemic heart disease: a retrospective cohort study of 129,290 births. Lancet 2001, 357(9273):2002-2006.

61. Ray JG, Vermeulen MJ, Schull MJ, Redelmeier DA: Cardiovascular health after maternal placental syndromes (CHAMPS): population-based retrospective cohort study. Lancet 2005, 366(9499):1797-1803.

62. Wikstrom A-K, Haglund B, Olovsson M, Lindeberg SN: The risk of maternal ischaemic heart disease after gestational hypertensive disease. $\mathrm{Br}\rfloor$ Obstet Gynaecol 2005, 112(11):1486-1491.

63. Wilson BJ, Watson MS, Prescott GJ, Sunderland S, Campbell DM, Hannaford $P$, Smith WC: Hypertensive diseases of pregnancy and risk of hypertension and stroke in later life: results from cohort study. BMJ 2003, 326(7394):845

64. Arnadottir GA, Geirsson RT, Arngrimsson R, Jonsdottir LS, Olafsson O: Cardiovascular death in women who had hypertension in pregnancy: a case-control study. Br J Obstet Gynaecol 2005, 112(3):286-292.

65. Funai EF, Friedlander Y, Paltiel O, Tiram E, Xue X, Deutsch L, Harlap S: Longterm mortality after preeclampsia. Epidemiology 2005, 16(2):206-215.

66. Irgens HU, Reisaeter L, Irgens LM, Lie RT: Long term mortality of mothers and fathers after pre-eclampsia: population based cohort study. BMJ 2001, 323(7323):1213-1217.

67. Jonsdottir LS, Arngrimsson R, Geirsson RT, Sigvaldason H, Sigfusson N: Death rates from ischemic heart disease in women with a history of hypertension in pregnancy. Acta Obstet Gynecol Scand 1995, 74(10):772-776.

68. Brown DW, Dueker N, Jamieson DJ, Cole JW, Wozniak MA, Stern BJ, Giles WH, Kittner SJ: Preeclampsia and the Risk of Ischemic Stroke Among Young Women: Results From the Stroke Prevention in Young Women Study. Stroke 2006, 37(4):1055-1059.

69. Garovic VD, Hayman SR: Hypertension in pregnancy: an emerging risk factor for cardiovascular disease. Nat Clin Pract Nephrol 2007, 3(11):613-622.
70. Chambers JC, Fusi L, Malik IS, Haskard DO, De Swiet M, Kooner JS: Association of maternal endothelial dysfunction with preeclampsia. JAMA 2001, 285(12):1607-1612.

71. North RA, Simmons D, Barnfather D, Upjohn M: What happens to women with preeclampsia? Microalbuminuria and hypertension following preeclampsia. Aust N Z J Obstet Gyneacol 1996, 36(3):233-238.

72. Melchiorre K, Sutherland GR, Liberati M, Thilaganathan B: Preeclampsia is associated with persistent postpartum cardiovascular impairment. Hypertens Res 2011, 58(4):709-715.

73. Rocca WA, Grossardt BR, Miller VM, Shuster LT, Brown RD Jr: Premature menopause or early menopause and risk of ischemic stroke. Menopause 2012, 19(3):272-277.

74. Chen S-J, Li H, Durand J, Oparil S, Chen Y-F: Estrogen reduces myointimal proliferation after balloon injury of rat carotid artery. Circulation 1996, 93:577-584.

75. Karas RH, Schulten H, Pare G, Aronovitz MJ, Ohlsson C, Gustafsson JA, Mendelsohn ME: Effects of estrogen on the vascular injury response in estrogen receptor alpha, beta (double) knockout mice. Circ Res 2001, 89:534-539.

76. White CR, Shelton J, Chen S-J, Darley-Usmar V, Allen L, Nabors C, Sanders PW, Chen Y-F, Oparil S: Estrogen restores endothelial cell function in an experimental model of vascular injury. Circulation 1998, 96:1624-1630.

77. Shuster LT, Rhodes DJ, Gostout BS, Grossardt BR, Rocca WA: Premature menopause or early menopause: long-term health consequences. Maturitas 2010, 65:161-166.

78. Barrett-Connor E, Bush TL: Estrogen and coronary heart disease in women. J Am Med Assoc 1991, 265(14):1861-1867.

79. Ernster VL, Bush TL, Huggins GR, Hullka BS, Kelsey JL, Schottenfeld D: Benefits and risks of menopausal estrogen and/or progestin hormone use. Prev Med 1988, 17:201-223.

80. Ettinger B, Friedman GD, Bush T, Quesenberry CP Jr: Reduced mortality associated with long-term postmenopausal estrogen therapy. Obstet Gynecol 1996, 87(1):6-12.

81. Bass KM, Bush TL: Estrogen therapy and cardiovascular risk in women. J La State Med Soc 1991, 143:33-39.

82. Bush TL, Barrett-Connor E, Cowan LD, Criqui MH, Wallace RB, Suchindran CM, Tyroler HA, Rifkind BM: Cardiovascular mortality and noncontraceptive use of estrogen in women: results from the Lipid Research Clinics Program Follow-up Study. Circulation 1987, 75:1102-1109.

83. Bush TL, Cowan LD, Barrett-Connor E, Criqui MH, Karon JM, Wallace RB, Tyroler HA, Rifkind BM: Estrogen use and all-cause mortality. preliminary results from the lipid research clinics program follow-up study. JAMA 1983, 249(7):903-906.

84. Miller VT, Larosa J, Barnabei V, Kessler C, Levin G, Smithroth A, Griffin M, Stoy $D B$, Bush $T$, Zacur $H$, et al: Effects of estrogen or estrogen/progestin regimens on heart disease risk factors in postmenopausal women. The Postmenopausal Estrogen/Progestin Interventions (PEPI) Trial. JAMA 1995, 273(3):199-208.

85. Hodis H, Mack W, Lobo R, Shoupe D, Sevanian A, Mahrer P, Selzer R, Liu C, Liu C, Azen S: Estrogen in the Prevention of Atherosclerosis. a randomized, double-blind, placebo-controlled trial. Ann Intern Med 2001, 135(11):939-953.

86. Clarkson TB, Appt SE: Coronary artery disease and postmenopausal hormone therapy: is there a time window for prevention? Gynaecol Forum 2004, 9:11-14.

87. Hodis HN, Bauer HJ, Rawlins DB, Mack WJ: A "window of opportunity:" The reduction of coronary heart disease and total mortality with menopausal therapies is age and time dependent. Brain Res 2011, 1379:244-252.

88. Rocca WA, Grossardt BR, Shuster LT: Oophorectomy, menopause, estrogen treatment, and cognitive aging: clinical evidence for a window of opportunity. Brain Res 2011, 1379:188-198.

89. Ashraf MS, Vongpatanasin W: Estrogen and hypertension. Curr Hypertens Rep 2006, 8(5):368-376

90. Angerer $P$, Stork $S$, von Schacky $C$ : Influence of 17 beta-oestradiol on blood pressure of postmenopausal women at high vascular risk. J Hypertens 2001, 19(12):2135-2142.

91. Scuteri A, Bos AJ, Brant LJ, Talbot L, Lakatta EG, Fleg JL: Hormone replacement therapy and longitudinal changes in blood pressure in postmenopausal women. Ann Intern Med 2001, 135(4):229-238.

92. Kawecka-Jaszcz K, Czarnecka D, Olszanecka A, Rajzer M, Jankowski P: The effect of hormone replacement therapy on arterial blood pressure and 
vascular compliance in postmenopausal women with arterial hypertension. J Hum Hypertens 2002, 16(7):509-516.

93. Andersen K, Launer LJ, Dewey ME, Letenneur L, Ott A, Copeland JR, Dartigues JF, Kragh-Sorensen P, Baldereschi M, Brayne C, et al: Gender differences in the incidence of $A D$ and vascular dementia: The EURODEM Studies. EURODEM Incidence Research Group. Neurology 1999, 53(9):1992-1997.

94. Fratiglioni L, Viitanen $M$, von Strauss E, Tontodonati V, Herlitz A, Winblad B: Very old women at highest risk of dementia and Alzheimer's disease: incidence data from the Kungsholmen Project, Stockholm. Neurology 1997, 48(1):132-138.

95. Miech RA, Breitner JC, Zandi PP, Khachaturian AS, Anthony JC, Mayer L: Incidence of $A D$ may decline in the early 90 s for men, later for women: The Cache County study. Neurology 2002, 58(2):209-218.

96. Lobo A, Lopez-Anton R, Santabarbara J, De-la-Camara C, Ventura T, Quintanilla MA, Roy JF, Campayo AJ, Lobo E, Palomo T, et al: Incidence and lifetime risk of dementia and Alzheimer's disease in a Southern European population. Acta Psychiatr Scand 2011, 124(5):372-383.

97. Aguero-Torres H, Fratiglioni L, Guo Z, Viitanen M, Winblad B: Prognostic factors in very old demented adults: a seven-year follow-up from a population-based survey in Stockholm. J Am Geriatr Soc 1998, 46(4):444-452.

98. Tschanz JT, Corcoran CD, Schwartz S, Treiber K, Green RC, Norton MC, Mielke MM, Piercy K, Steinberg M, Rabins PV, et al: Progression of cognitive, functional, and neuropsychiatric symptom domains in a population cohort with Alzheimer dementia: the cache county dementia progression study. Am J Geriatr Psychiatry 2011, 19(6):532-542.

99. Mielke MM, Leoutsakos JM, Corcoran CD, Green RC, Norton MC, WelshBohmer KA, Tschanz JT, Lyketsos CG: Effects of Food and Drug Administration-approved medications for Alzheimer's disease on clinical progression. Alzheimers Dement 2012, 8(3):180-187.

100. Rhodes M, OToole S, Wright S, Czambel R, Rubin R: Sexual diergism in rat hypothalamic-pituitary-adrenal axis responses to cholinergic stimulation and antagonism. Brain Res Bull 2001, 54:101-113.

101. Luine V, Renner K, McEwen B: Sex-dependent differences in estrogen regulation of choline acetyltransferase are altered by neonatal treatments. Endocrinol Metab Clin North Am 1986, 119:874-878.

102. Hortnagl H, Hansen L, Kindel G, Schneider B, El Tamer A, Hanin I: Sex differences and estrous cycle-variations in the AF64A-induced cholinergic deficit in the rat hippocampus. Brain Res Bull 1993, 31:129-34

103. Wang R, Schorer-Apelbaum D, Weinstock M: Testosterone mediates sex difference in hypothermia and cholinesterase inhibition by rivastigmine. Eur J Pharmacol 2001, 433:73-79.

104. Wang $\mathrm{RH}$, Bejar C, Weinstock M: Gender differences in the effect of rivastigmine on brain cholinesterase activity and cognitive function in rats. Neuropharmacology 2000, 39:497-506.

105. Vinters HV: Cerebral amyloid angiopathy. a critical review. Stroke 1987 18:311-324.

106. Kalaria RN, Hedera P: Differential degeneration of the cerebral microvasculature in Alzheimer's disease. Neuroreport 1995, 6:477-480.

107. Perlmutter LS, Chui HC: Microangiopathy, the vascular basement membrane and Alzheimer's disease: a review. Brain Res Bull 1990, 24:677-686.

108. Sparks DL, Hunsaker JC 3rd, Scheff SW, Kryscio RJ, Henson JL, Markesbery WR: Cortical senile plaques in coronary artery disease, aging and Alzheimer's disease. Neurobiol Aging 1990, 11(6):601-607.

109. Skoog I, Lernfelt B, Landahl S, Palmertz B, Andreasson LA, Nilsson L, Persson G, Oden A, Svanborg A: 15-year longitudinal study of blood pressure and dementia. Lancet 1996, 347(9009):1141-1145.

110. Launer LJ, Ross GW, Petrovitch H, Masaki K, Foley D, White LR, Havlik RJ: Midlife blood pressure and dementia: the Honolulu-Asia aging study. Neurobiol Aging 2000, 21(1):49-55.

111. Hofman A, Ott A, Breteler MM, Bots ML, Slooter AJ, van Harskamp F, van Duijn CN, Van Broeckhoven C, Grobbee DE: Atherosclerosis, apolipoprotein $E$, and prevalence of dementia and Alzheimer's disease in the Rotterdam Study. Lancet 1997, 349(9046):151-154.

112. Ott A, Breteler MM, de Bruyne MC, van Harskamp F, Grobbee DE, Hofman A: Atrial fibrillation and dementia in a population-based study. the Rotterdam study. Stroke 1997, 28(2):316-321.

113. Yoshitake T, Kiyohara Y, Kato I, Ohmura T, Iwamoto H, Nakayama K, Ohmori S, Nomiyama K, Kawano H, Ueda K, et al: Incidence and risk factors of vascular dementia and Alzheimer's disease in a defined elderly Japanese population: the Hisayama Study. Neurology 1995, 45(6):1161-1168.
114. Ott A, Stolk RP, van Harskamp F, Pols HA, Hofman A, Breteler MM: Diabetes mellitus and the risk of dementia: The Rotterdam Study. Neurology 1999 53(9):1937-1942

115. Gustafson D, Rothenberg E, Blennow K, Steen B, Skoog I: An 18-year follow-up of overweight and risk of Alzheimer disease. Arch Intern Med 2003, 163(13):1524-1528

116. Honig LS, Tang MX, Albert S, Costa R, Luchsinger J, Manly J, Stern Y, Mayeux R: Stroke and the risk of Alzheimer disease. Arch Neurol 2003, 60(12):1707-1712.

117. Mielke MM, Rosenberg P, Tschanz JT, Cook L, Corcoran C, Hayden KM, Norton M, Rabins PVR, Green R, Welsh-Bohmer K, et al: Vascular factors predict rate of progression in Alzheimer's disease. Neurology 2007 69:1850-1858.

118. Zeeman GG, Fleckenstein JL, Twickler DM, Cunningham FG: Cerebral infarction in eclampsia. Am J Obstet Gynecol 2004, 190(3):714-720.

119. Wagner S, Acquah L, Lindell E, Craici I, Wingo M, Rose C, White W, August P, Garovic V: Posterior Reversible Encephalopathy Syndrome (PRES) and Eclampsia: Pressing the Case for More Aggressive Blood Pressure Control. Mayo Clin Proc 2011, 86:851-856.

120. van Straaten EC, Harvey D, Scheltens P, Barkhof F, Petersen RC, Thal L, Jack CR Jr, DeCarli C: Periventricular white matter hyperintensities increase the likelihood of progression from amnestic mild cognitive impairment to dementia. J Neurol 2008, 255(9):1302-1308.

121. Smith EE, Egorova S, Blacker D, Killiany RJ, Muzikansky A, Dickerson BC, Tanzi RE, Albert MS, Greenberg SM, Guttmann CR: Magnetic resonance imaging white matter hyperintensities and brain volume in the prediction of mild cognitive impairment and dementia. Arch Neurol 2008, 65(1):94-100.

122. Aukes AM, De Groot JC, Aarnoudse JG, Zeeman GG: Brain lesions several years after eclampsia. Am J Obstet Gynecol 2009, 200(5):504. e501-505.

123. Brusse I, Duvekot J, Jongerling J, Steegers E, De Koning I: Impaired maternal cognitive functioning after pregnancies complicated by severe pre-eclampsia: a pilot case-control study. Acta Obstet Gynecol Scand 2008, 87(4):408-412

124. Toda N, Ayajiki K, Okamura T: Cerebral blood flow regulation by nitric oxide in neurological disorders. Can J Physiol Pharmacol 2009, 87(8):581-594

125. Lavi S, Gaitini D, Milloul V, Jacob G: Impaired cerebral CO2 vasoreactivity: association with endothelial dysfunction. Am J Physiol Heart Circ Physiol 2006, 291(4):H1856-1861

126. Galvin SD, Celi LA, Thomas KN, Clendon TR, Galvin IF, Bunton RW, Ainslie PN: Effects of age and coronary artery disease on cerebrovascular reactivity to carbon dioxide in humans. Anaesth Intensive Care 2010, 38(4):710-717.

127. Katusic ZS, Vanhoutte PM: Anoxic contractions in isolated canine cerebral arteries: Contribution of endothelium-derived factors, metabolites of arachidonic acid and calcium entry. J Cardiovasc Pharmacol 1986, 8:S97-S101.

128. Katusic ZS, Vanhoutte PM: Superoxide anion is an endothelium-derived contracting factor. Am J Physiol 1989, 257:H33-H37.

129. Guo J, Krause DN, Horne J, Weiss JH, Li X, Duckles SP: Estrogen-receptormediated protection of cerebral endothelial cell viability and mitochondrial function after ischemic insult in vitro. J Cereb Blood Flow Metab 2010, 30(3):545-554

130. Xie A, Skatrud JB, Morgan B, Chenuel B, Khayat R, Reichmuth K, Lin J, Dempsey JA: Influence of cerebrovascular function on the hypercapnic ventilatory response in healthy humans. J Physiol 2006, 577(Pt 1):319-329.

131. Barnes JN, Schmidt JE, Nicholson WT, Joyner MJ: Cyclooxygenase inhibition abolishes age-related differences in cerebral vasodilator responses to hypercapnia. J App/ Physio/ 2012, 112(11):1884-1890.

132. Kastrup A, Dichgans J, Niemeier M, Schabet M: Changes of cerebrovascular CO2 reactivity during normal aging. Stroke 1998, 29(7):1311-1314.

133. Deegan BM, Sorond FA, Galica A, Lipsitz LA, O'Laighin G, Serrador JM: Elderly women regulate brain blood flow better than men do. Stroke 2011, 42(7):1988-1993.

134. Lampinen KH, Ronnback M, Kaaja RJ, Groop PH: Impaired vascular dilatation in women with a history of pre-eclampsia. J Hypertens 2006 24(4):751-756.

135. Celermajer DS, Sorensen KE, Spiegelhalter DJ, Georgakopoulos D, Robinson J, Deanfield JE: Aging is associated with endothelial dysfunction in healthy men years before the age-related decline in women. J Am Coll Cardiol 1994, 24:471-476. 
136. Kawano H, Motoyama T, Kugiyama K, Hirashima O, Ohgushi M, Fujii H, Ogawa $\mathrm{H}$, Yasue $\mathrm{H}$ : Gender difference in improvement of endotheliumdependent vasodilation after estrogen supplementation. J Am Coll Cardiol 1997, 30:914-919.

137. Gerhard M, Walsh BW, Tawakol A, Haley EA, Creager SJ, Seely EW, Ganz P, Creager MA: Estradiol therapy combined with progesterone and endothelium-dependent vasodilation in postmenopausal women. Circulation 1998, 98(12):1158-1163.

138. Sorensen KE, Dorup I, Hermann AP, Mosekilde L: Combined hormone replacement therapy does not protect women against the age-related decline in endothelium-dependent vasomotor function. Circulation 1998 97(13):1234-1238.

139. Emre A, Sahin S, Erzik C, Nurkalem Z, Oz D, Cirakoglu B, Yesilcimen K, Ersek $B$ : Effect of hormone replacement therapy on plasma lipoproteins and apolipoproteins, endothelial function and myocardial perfusion in postmenopausal women with estrogen receptor-alpha IVS1-397 C/C genotype and established coronary artery disease. Cardiology 2006, 106(1):44-50.

140. Sudhir K, Chou TM, Messina LM, Hutchison SJ, Korach KS, Chatterjee K, Rubanyi GM: Endothelial dysfunction in a man with disruptive mutation in oestrogen-receptor gene. Lancet 1997, 349:1146-1147.

141. Sudhir K, Komesaroff PA: Cardiovascular actions of estrogens in men. J Clin Endocrinol Metab 1999, 84:3411-3415.

142. Lew R, Komesaroff P, Williams M, Dawood T, Sudhir K: Endogenous estrogens influence endothelial function in young men. Circ Res 2003, 93:1127-1133

143. Resnick SM, Metter EJ, Zonderman AB: Estrogen replacement therapy and longitudinal decline in visual memory. A possible protective effect? Neurology 1997, 49(6):1491-1497.

144. Rice MM, Graves AB, McCurry SM, Gibbons LE, Bowen JD, McCormick WC, Larson EB: Postmenopausal estrogen and estrogen-progestin use and 2 year rate of cognitive change in a cohort of older Japanese American women: The Kame Project. Arch Intern Med 2000, 160(11):1641-1649.

145. Steffens DC, Norton MC, Plassman BL, Tschanz JT, Wyse BW, Welsh-Bohmer KA, Anthony JC, Breitner JC: Enhanced cognitive performance with estrogen use in nondemented community-dwelling older women. J Am Geriatr Soc 1999, 47(10):1171-1175.

146. Grodstein F, Chen J, Pollen DA, Albert MS, Wilson RS, Folstein MF, Evans DA, Stampfer MJ: Postmenopausal hormone therapy and cognitive function in healthy older women. J Am Geriatr Soc 2000, 48(7):746-752.

147. Matthews K, Cauley J, Yaffe K, Zmuda JM: Estrogen replacement therapy and cognitive decline in older community women. J Am Geriatr Soc 1999, 47(5):518-523.

148. O'Hara R, Schroder CM, Bloss C, Bailey AM, Alyeshmerni AM, Mumenthaler MS, Friedman LF, Yesavage JA: Hormone replacement therapy and longitudinal cognitive performance in postmenopausal women. Am J Geriatr Psychiatry 2005, 13(12):1107-1110.

149. de Moraes SA, Szklo M, Knopman D, Park E: Prospective assessment of estrogen replacement therapy and cognitive functioning: atherosclerosis risk in communities study. Am J Epidemiol 2001, 154(8):733-739.

150. File SE, Heard JE, Rymer J: Trough oestradiol levels associated with cognitive impairment in post-menopausal women after 10 years of oestradiol implants. Psychopharmacology (Berl) 2002, 161(1):107-112.

151. Fillenbaum GG, Hanlon JT, Landerman LR, Schmader KE: Impact of estrogen use on decline in cognitive function in a representative sample of older community-resident women. Am J Epidemio/ 2001, 153(2):137-144

152. Craig MC, Maki PM, Murphy DG: The Women's Health Initiative Memory Study: findings and implications for treatment. Lancet Neurol 2005, 4(3):190-194.

153. Shumaker SA, Reboussin BA, Espeland MA, Rapp SR, McBee WL, Dailey M, Bowen D, Terrell T, Jones BN: The Women's Health Initiative Memory Study (WHIMS): a trial of the effect of estrogen therapy in preventing and slowing the progression of dementia. Control Clin Trials 1998, 19(6):604-621.

154. Rocca WA, Bower JH, Maraganore DM, Ahlskog JE, Grossardt BR, de Andrade $M$, Melton $L J$ 3rd: Increased risk of cognitive impairment or dementia in women who underwent oophorectomy before menopause. Neurology 2007, 69(11):1074-1083

155. Hogervorst E, Williams J, Budge M, Riedel W, Jolles J: The nature of the effect of female gonadal hormone replacement therapy on cognitive function in post-menopausal women: a meta-analysis. Neuroscience 2000, 101(3):485-512
156. LeBlanc ES, Janowsky J, Chan BK, Nelson HD: Hormone replacement therapy and cognition: systematic review and meta-analysis. JAMA 2001, 285(11):1489-1499.

157. Yaffe K, Sawaya G, Lieberburg I, Grady D: Estrogen therapy in postmenopausal women: effects on cognitive function and dementia. JAMA 1998, 279(9):688-695.

158. Sherwin BB, Henry JF: Brain aging modulates the neuroprotective effects of estrogen on selective aspects of cognition in women: a critical review. Front Neuroendocrinol 2008, 29(1):88-113.

159. Joffe H, Hall JE, Gruber S, Sarmiento IA, Cohen LS, Yurgelun-Todd D, Martin KA: Estrogen therapy selectively enhances prefrontal cognitive processes: a randomized, double-blind, placebo-controlled study with functional magnetic resonance imaging in perimenopausal and recently postmenopausal women. Menopause 2006, 13(3):411-422.

160. Phillips SM, Sherwin BB: Effects of estrogen on memory function in surgically menopausal women. Psychoneuroendocrinology 1992, 17(5):485-495.

161. Schmidt R, Fazekas F, Reinhart B, Kapeller P, Fazekas G, Offenbacher H, Eber $B$, Schumacher M, Freidl W: Estrogen replacement therapy in older women: a neuropsychological and brain MRI study. J Am Geriatr Soc 1996 44(11):1307-1313.

162. Espeland MA, Rapp SR, Shumaker SA, Brunner R, Manson JE, Sherwin BB, Hsia J, Margolis KL, Hogan PE, Wallace R, et al: Conjugated equine estrogens and global cognitive function in postmenopausal women: Women's Health Initiative Memory Study. JAMA 2004, 291(24):2959-2968.

163. Espeland MA, Tindle HA, Bushnell CA, Jaramillo SA, Kuller LH, Margolis KL, et al: Brain Volumes, Cognitive Impairment, and Conjugated Equine Estrogens. J Gerontol A Biol Sci Med Sci 2009, 64:1243-1250.

164. Rapp SR, Espeland MA, Shumaker SA, Henderson WW, Brunner RL, Manson JE, Gass ML, Stefanick ML, Lane DS, Hays J, et al: Effect of estrogen plus progestin on global cognitive function in postmenopausal women: the Women's Health Initiative Memory Study: a randomized controlled trial. JAMA 2003, 289(20):2663-2672.

165. Shaywitz SE, Naftolin F, Zelterman D, Marchione KE, Holahan JM, Palter SF, Shaywitz BA: Better oral reading and short-term memory in midlife, postmenopausal women taking estrogen. Menopause 2003, 10(5):420-426.

166. Shumaker SA, Legault C, Kuller L, Rapp SR, Thal L, Lane DS, Fillit H, Stefanick $M L$, Hendrix SL, Lewis CE, et al: Conjugated equine estrogens and incidence of probable dementia and mild cognitive impairment in postmenopausal women: Women's Health Initiative Memory Study. JAMA 2004, 291(24):2947-2958

167. Morrison JH, Brinton RD, Schmidt PJ, Gore AC: Estrogen, menopause, and the aging brain: how basic neuroscience can inform hormone therapy in women. J Neurosci 2006, 26(41):10332-10348.

168. Sherwin BB: Estrogen and/or androgen replacement therapy and cognitive functioning in surgically menopausal women. Psychoneuroendocrinology 1988, 13(4):345-357.

169. Asthana S, Brinton RD, Henderson WW, McEwen BS, Morrison JH, Schmidt PJ: Frontiers proposal. National Institute on Aging "bench to bedside: estrogen as a case study". Age (Dordr) 2009, 31(3):199-210.

170. Resnick SM, Henderson WW: Hormone therapy and risk of Alzheimer disease: a critical time.[see comment][comment]. JAMA 2002, 288(17):2170-2172

171. Henderson WW, Benke KS, Green RC, Cupples LA, Farrer LA: Postmenopausal hormone therapy and Alzheimer's disease risk: interaction with age. J Neurol Neurosurg Psychiatry 2005, 76(1):103-105.

172. Maki PM: Hormone therapy and cognitive function: is there a critical period for benefit? Neuroscience 2006, 138(3):1027-1030.

173. Murphy DD, Segal M: Regulation of dendritic spine density in cultured rat hippocampal neurons by steroid hormones. J Neurosci 1996, 16(13):4059-4068.

174. Morrison JH: A mechanism emerges for the critical period hypothesis for estrogen treatment. Proc Natl Acad Sci USA 2011, 108(35):14375-14376. doi:10.1073/pnas.1111672108.

175. Aenlle KK, Kumar A, Cui L: Jackson TC. Foster TC: Estrogen effects on cognition and hippocampal transcription in middle-aged mice. Neurobiol Aging; 2007

176. Gould E, Woolley CS, Frankfurt M, McEwen BS: Gonadal steroids regulate dendritic spine density in hippocampal pyramidal cells in adulthood. J Neurosci 1990, 10(4):1286-1291.

177. Woolley CS, Gould E, Frankfurt M, McEwen BS: Naturally occurring fluctuation in dendritic spine density on adult hippocampal pyramidal neurons. J Neurosci 1990, 10(12):4035-4039. 
178. Gibbs RB: Estrogen and nerve growth factor-related systems in brain. Effects on basal forebrain cholinergic neurons and implications for learning and memory processes and aging. Ann N Y Acad Sci 1994, 743:165-196. discussion 197-169.

179. Gibbs RB, Aggarwal P: Estrogen and basal forebrain cholinergic neurons: implications for brain aging and Alzheimer's disease-related cognitive decline. Horm Behav 1998, 34(2):98-111.

180. Luine VN: Estradiol increases choline acetyltransferase activity in specific basal forebrain nuclei and projection areas of female rats. Exp Neurol 1985, 89(2):484-490.

181. Markowska AL, Savonenko AV: Effectiveness of estrogen replacement in restoration of cognitive function after long-term estrogen withdrawal in aging rats. J Neurosci 2002, 22(24):10985-10995.

182. Chen VM, Ahamed J, Versteeg HH, Berndt MC, Ruf W, Hogg PJ: Evidence for activation of tissue factor by an allosteric disulfide bond. Biochem Cell Biol 2006, 45:12020-12028.

183. Jaffe $A B$, Toran-Allerand CD, Greengard P, Gandy SE: Estrogen regulates metabolism of Alzheimer amyloid beta precursor protein. J Biol Chem 1994, 269(18):13065-13068.

184. Green PS, Simpkins JW: Neuroprotective effects of estrogens: potential mechanisms of action. Int J Develop Neurosci 2000, 18:347-358.

185. Green PS, Gridley KE, Simpkins JW: Nuclear estrogen receptorindependent neuroprotection by estratrienes: a novel interaction with glutathione. Neuroscience 1998, 84(1):7-10.

186. Greene RA: Estrogen and cerebral blood flow: a mechanism to explain the impact of estrogen on the incidence and treatment of Alzheimer's disease. Int J Fertil Womens Med 2000, 45(4):253-257.

187. Dekaban AS: Changes in brain weights during the span of human life: relation of brain weights to body heights and body weights. Ann Neurol 1978, 4(4):345-356

188. Sowell ER, Peterson BS, Thompson PM, Welcome SE, Henkenius AL, Toga AW: Mapping cortical change across the human life span. Nat Neurosci 2003, 6(3):309-315

189. Liu RS, Lemieux L, Bell GS, Sisodiya SM, Shorvon SD, Sander JW, Duncan JS: A longitudinal study of brain morphometrics using quantitative magnetic resonance imaging and difference image analysis. Neuroimage 2003, 20(1):22-33.

190. Bobinski M, Wegiel J, Tarnawski M, Reisberg B, de Leon MJ, Miller DC, Wisniewski HM: Relationships between regional neuronal loss and neurofibrillary changes in the hippocampal formation and duration and severity of Alzheimer disease. J Neuropathol Exp Neurol 1997, 56(4):414-420.

191. Kantarci K, Jack CRJ: Quantitative magnetic resonance techniques as surrogate markers in Alzheimer's disease. NeuroRx 2004, 1:196-205.

192. Jagust WJ, Zheng L, Harvey DJ, Mack WJ, Vinters HV, Weiner MW, Ellis WG, Zarow C, Mungas D, Reed BR, et al: Neuropathological basis of magnetic resonance images in aging and dementia. Ann Neurol 2008, 63(1):72-80.

193. Seliger SL, Longstreth WT Jr, Katz R, Manolio T, Fried LF, Shlipak M, Stehman-Breen CO, Newman A, Sarnak M, Gillen DL, et al: Cystatin C and subclinical brain infarction. J Am Soc Nephrol 2005, 16(12):3721-3727.

194. Schmidt R, Ropele S, Enzinger C, Petrovic K, Smith S, Schmidt H, Matthews PM, Fazekas F: White matter lesion progression, brain atrophy, and cognitive decline: the Austrian stroke prevention study. Ann Neurol 2005, 58(4):610-616.

195. Vermeer SE, Prins ND, den Heijer T, Hofman A, Koudstaal PJ, Breteler MM: Silent brain infarcts and the risk of dementia and cognitive decline. N Engl J Med 2003, 348(13):1215-1222.

196. Luchsinger J, Brickman A, Reitz C, Schupf N, Manly J, Tang M, Small S, Mayeux R, DeCarli C, Brown T: Cerebrovascular disease in mild cognitive impairment. Alzheimers Dement 2008, 4(4(2)):T131.

197. DeCarli C, Miller BL, Swan GE, Reed T, Wolf PA, Carmelli D: Cerebrovascula and brain morphologic correlates of mild cognitive impairment in the National Heart, Lung, and Blood Institute Twin Study. Arch Neurol 2001, 58(4):643-647

198. Kantarci K, Miller VM, Zais TG, Gunter JL, Jack CRJ: Brain Volume Changes in Recently Menopausal Women in a Hormone Replacement Trial. Climacteric 2008, 11(2):342. 264.

199. Bartzokis G, Cummings JL, Sultzer D, Henderson WW, Nuechterlein KH, Mintz $\mathrm{J}$ : White matter structural integrity in healthy aging adults and patients with Alzheimer disease: a magnetic resonance imaging study. Arch Neurol 2003, 60(3):393-398
200. Yoshita M, Fletcher E, Harvey D, Ortega M, Martinez O, Mungas DM, Reed BR, DeCarli CS: Extent and distribution of white matter hyperintensities in normal aging, MCl, and AD. Neurology 2006, 67(12):2192-2198.

201. Greenberg DL, Payne ME, MacFall JR, Provenzale JM, Steffens DC, Krishnan RR: Differences in brain volumes among males and female hormonetherapy users and nonusers. Psychiatry Res 2006, 147(2-3):127-134.

202. Low LF, Anstey KJ, Maller J, Kumar R, Wen W, Lux O, Salonikas C, Naidoo D, Sachdev P: Hormone replacement therapy, brain volumes and white matter in postmenopausal women aged 60-64 years. Neuroreport 2006, 17(1):101-104.

203. Boccardi M, Ghidoni R, Govoni S, Testa C, Benussi L, Bonetti M, Binetti G, Frisoni GB: Effects of hormone therapy on brain morphology of healthy postmenopausal women: a Voxel-based morphometry study. Menopause 2006, 13(4):584-591.

204. Eberling JL, Wu C, Haan MN, Mungas D, Buonocore M, Jagust WJ: Preliminary evidence that estrogen protects against age-related hippocampal atrophy. Neurobiol Aging 2003, 24(5):725-732.

205. Lord C, Buss C, Lupien SJ, Pruessner JC: Hippocampal volumes are larger in postmenopausal women using estrogen therapy compared to past users, never users and men: a possible window of opportunity effect. Neurobiol Aging 2008, 29(1):95-101.

206. Erickson Kl, Colcombe SJ, Raz N, Korol DL, Scalf P, Webb A, Cohen NJ, McAuley E, Kramer AF: Selective sparing of brain tissue in postmenopausal women receiving hormone replacement therapy. Neurobiol Aging 2005, 26(8):1205-1213.

207. Ghidoni R, Boccardi M, Benussi L, Testa C, Villa A, Pievani M, Gigola L, Sabattoli F, Barbiero L, Frisoni GB, et al: Effects of estrogens on cognition and brain morphology: involvement of the cerebellum. Maturitas 2006, 54(3):222-228

208. Ha DM, Xu J, Janowsky JS: Preliminary evidence that long-term estrogen use reduces white matter loss in aging. Neurobiol Aging 2007, 28(12) 1936-1940.

209. Resnick SM, Espeland MA, Jaramillo SA, Hirsch C, Stefanick ML, Murray AM, Ockene J, Davatzikos C: Postmenopausal hormone therapy and regional brain volumes: the WHIMS-MRI Study. Neurology 2009, 72(2):135-142

210. Coker LH, Hogan PE, Bryan NR, Kuller LH, Margolis KL, Bettermann K, Wallace RB, Lao Z, Freeman R, Stefanick ML, et al: Postmenopausal hormone therapy and subclinical cerebrovascular disease: the WHIMS-MRI Study. Neurology 2009, 72(2):125-134.

211. Kuller LH, Margolis KL, Gaussoin SA, Bryan NR, Kerwin D, Limacher M, Wassertheil-Smoller S, Williamson J, Robinson JG: Relationship of hypertension, blood pressure, and blood pressure control with white matter abnormalities in the Women's Health Initiative Memory Study (WHIMS)-MRI trial. J Clin Hypertens (Greenwich) 2010 12(3):203-212.

212. Rose SE, Chen F, Chalk JB, Zelaya FO, Strugnell WE, Benson M, Semple J, Doddrell DM: Loss of connectivity in Alzheimer's disease: an evaluation of white matter tract integrity with colour coded MR diffusion tensor imaging. J Neurol Neurosurg Psychiatry 2000, 69(4):528-530.

213. Sandson TA, Felician O, Edelman RR, Warach S: Diffusion-weighted magnetic resonance imaging in Alzheimer's disease. Dement Geriatr Cogn Disord 1999, 10(2):166-171.

214. O'Sullivan M, Summers PE, Jones DK, Jarosz JM, Williams SC, Markus HS: Normal-appearing white matter in ischemic leukoaraiosis: a diffusion tensor MRI study. Neurology 2001, 57(12):2307-2310.

215. Lee DY, Fletcher E, Martinez O, Ortega M, Zozulya N, Kim J, Tran J, Buonocore M, Carmichael O, DeCarli C: Regional pattern of white matter microstructural changes in normal aging, MCl, and AD. Neurology 2009, 73(21):1722-1728.

216. Kantarci K: Diffusion Tensor Imaging in Alzheimer's Disease. Curr Med Imaging Rev 2011, 7(1):28-33.

217. Kantarci K, Senjem ML, Avula R, Zhang B, Samikoglu AR, Weigand SD, Przybelski SA, Edmonson HA, Vemuri P, Knopman DS, et al: Diffusion tensor imaging and cognitive function in older adults with no dementia. Neurology 2011, 77(1):26-34.

218. O'Sullivan M, Jones DK, Summers PE, Morris RG, Williams SC, Markus HS: Evidence for cortical "disconnection" as a mechanism of age-related cognitive decline. Neurology 2001, 57(4):632-638.

219. Davis SW, Dennis NA, Buchler NG, White LE, Madden DJ, Cabeza R: Assessing the effects of age on long white matter tracts using diffusion tensor tractography. Neuroimage 2009, 46(2):530-541. 
220. Sperling RA, Aisen PS, Beckett LA, Bennett DA, Craft S, Fagan AM, Iwatsubo $T$, Jack CR Jr, Kaye J, Montine TJ, et al: Toward defining the preclinical stages of Alzheimer's disease: recommendations from the National Institute on Aging-Alzheimer's Association workgroups on diagnostic guidelines for Alzheimer's disease. Alzheimers Dement 2011, 7(3):280-292.

221. Ikonomovic MD, Klunk WE, Abrahamson EE, Mathis CA, Price JC, Tsopelas ND, Lopresti BJ, Ziolko S, Bi W, Paljug WR, et al: Post-mortem correlates of in vivo PiB-PET amyloid imaging in a typical case of Alzheimer's disease. Brain 2008, 131(Pt 6):1630-1645.

222. Morris JC, Roe CM, Xiong C, Fagan AM, Goate AM, Holtzman DM, Mintun MA: APOE predicts amyloid-beta but not tau Alzheimer pathology in cognitively normal aging. Ann Neurol 2010, 67(1):122-131.

223. Kantarci K, Lowe V, Przybelski SA, Weigand SD, Senjem ML, Ivnik RJ, Preboske GM, Roberts R, Geda YE, Boeve BF, et al: APOE Modifies the Association Between A-Beta load and Cognition in Cognitively Normal Older Adults. Neurology 2012, 78(4):232-240

224. Cohen RA, Shepherd JT, Vanhoutte PM: Inhibitory role of the endothelium in the response of isolated coronary arteries to platelets. Science 1983 221:273-274.

225. Houston DS, Shepherd JT, Vanhoutte PM: Aggregating human platelets cause direct contraction and endothelium-dependent relaxation of isolated canine coronary arteries. J Clin Invest 1986, 78:539-544.

226. Lorenz RR, Vanhoutte PM: Prejunctional adrenergic inhibition by aggregating platelets in canine blood vessels. Am J Physiol 1985, 249:H685-H689.

227. Bracamonte MP, Rud KS, Owen WG, Miller VM: Ovariectomy increases mitogens and platelet-induced proliferation of arterial smooth muscle. Am J Physiol Heart Circ Physiol 2002, 283:H853-H860.

228. Lewis DA, Avsar M, LaBreche P, Bracamonte MP, Jayachandran M, Miller VM: Treatment with raloxifene and 17 beta-estradiol differentially modulates nitic oxide and prostanoids in venous endothelium and platelets of ovariectomized pigs. J Cardiovasc Pharmacol 2006, 48(5):231-238.

229. Bracamonte MP, Miller VM: Vascular effects of estrogens: arterial protection versus venous thrombotic risk. Trends Endocrinol Metab 2001, 12:204-209.

230. Jayachandran M, Miller VM: Ovariectomy upregulates expression of estrogen receptors, NOS, and HSPs in porcine platelets. Am J Physio Heart Circ Physiol 2002, 283:H220-H226.

231. Jayachandran M, Miller VM: Human platelets contain estrogen receptor a, caveolin-1 and estrogen receptor associated proteins. Platelets 2003 $14: 75-81$

232. Jayachandran M, Owen WG, Miller VM: Effects of ovariectomy on aggregation, secretion, and metalloproteinases in porcine platelets. Am J Physiol Heart Circ Physiol 2003, 284:H1679-H1685.

233. Jayachandran M, Mukherjee R, Steinkamp T, LaBreche P, Bracamonte MP, Okano H, Owen WG, Miller VM: Differential effects of 17b-estradiol, conjugated equine estrogen and raloxifene on mRNA expression, aggregation and secretion in platelets. Am J Physiol Heart Circ Physiol 2005, 288:H2355-H2362.

234. Lewis DA, Bracamonte MP, Rud KS, Miller VM: Genome and hormones: gender differences in physiology selected contribution: effects of sex and ovariectomy on responses to platelets in porcine femoral veins. J App/ Physiol 2001, 91:2823-2830.

235. Kobayashi T, Tokunaga N, Sugimura M, Suzuki K, Kanayama N, Nishiguchi T, Terao T: Coagulation/fibrinolysis disorder in patients with severe preeclampsia. Semin Thromb Hemost 1999, 25(5):451-454.

236. Bosio PM, Cannon S, McKenna PJ, O'Herlihy C, Conroy R, Brady H: Plasma P-selectin is elevated in the first trimester in women who subsequently develop pre-eclampsia. BJOG 2001, 108(7):709-715.

237. Mellembakken JR, Solum NO, Ueland T, Videm V, Aukrust P: Increased concentrations of soluble CD40 ligand, RANTES and GRO-alpha in preeclampsia-possible role of platelet activation. Thromb Haemost 2001, 86(5):1272-1276

238. Torres PJ, Escolar G, Palacio M, Gratacos E, Alonso PL, Ordinas A: Platelet sensitivity to prostaglandin E1 inhibition is reduced in pre-eclampsia but not in nonproteinuric gestational hypertension. Br J Obstet Gynaecol 1996, 103(1):19-24.

239. Valera MC, Parant O, Vayssiere C, Arnal JF, Payrastre B: Physiologic and pathologic changes of platelets in pregnancy. Platelets 2010, 21(8):587-595.
240. Stellos K, Panagiota V, Kogel A, Leyhe T, Gawaz M, Laske C: Predictive value of platelet activation for the rate of cognitive decline in Alzheimer's disease patients. J Cereb Blood Flow Metab 2010, 30(11):1817-1820.

241. Hochstrasser T, Ehrlich D, Marksteiner J, Sperner-Unterweger B, Humpel C: Matrix Metalloproteinase-2 and Epidermal Growth Factor are Decreased in Platelets of Alzheimer Patients. Curr Alzheimer Res 2011, 9:982-989. doi:10.2174/156720512803251156.

242. Jablonski M, Maciejewski R, Januszewski S, Ulamek M, Pluta R: One year follow up in ischemic brain injury and the role of Alzheimer factors. Physiol Res 2011, 60(Suppl 1):S113--119.

243. Berckmans RJ, Neiuwland R, Boing AN, Romijn FP, Hack CE, Sturk A: Cell-derived microparticles circulate in healthy humans and support low grade thrombin generation. Thromb Haemost 2001, 85(4):639-646.

244. Zwaal RF, Schroit AJ: Pathophysiologic implications of membrane phospholipid asymmetry in blood cells. Blood 1997, 89:1121-1132

245. Morel O, Toti F, Hugel B, Camoin-Jau L, Dignat-George F, Freyssinet JM: Procoagulant Microparticles: Disrupting the Vascular Homeostasis Equation? Arterioscler Thromb Vasc Biol 2006, 26:2594-2604.

246. Jayachandran M, Litwiller RD, Owen WG, Miller VM: Circulating microparticles and endogenous estrogen in newly menopausal women. Climacteric 2009, 12:177-184

247. VanWijk MJ, VanBavel E, Sturk A, Nieuwland R: Microparticles in cardiovascular diseases. Cardiovasc Res 2003, 59(2):277-287.

248. Jayachandran M, Litwiller RD, Owen WG, Heit JA, Behrenbeck TR, Mulvagh SL, Araoz PA, Budoff MJ, Harman SM, Miller VM: Characterization of blood borne microparticles as markers of premature coronary calcification in newly menopausal women. Am J Physiol Heart Circ Physiol 2008, 295:931-938.

249. Jayachandran M, Litwiller RD, Lahr BD, Bailey KR, Owen WG, Mulvagh SL, Heit JA, Hodis HN, Harman SM, Miller VM: Alterations in Platelet Function and Cell-Derived Microvesicles in Recently Menopausal Women: Relationship to Metabolic Syndrome and Atherogenic Risk. J Cardiovasc Transl Res 2011, 4(6):811-822.

250. Harman SM, Brinton EA, Cedars M, Lobo R, Manson JE, Merriam GR, Miller VM, Naftolin F, Santoro N: KEEPS: The Kronos Early Estrogen Prevention Study. Climacteric 2005, 8:3-12.

251. Raz L, Jayachandran M, Tosakulwong N, Lesnick TG, Wille SM, Murphy MC, Senjem ML, Vermuri $P$, Jack CRJ, Miller VM, et al: Thrombogenic microvesicles and white matter hyperintensities in postmenopausal women. Neurology 2012. doi:10.1212/WNL.0b013e3182840c9f.

doi:10.1186/2042-6410-4-6

Cite this article as: Miller et al:: Sex-specific risk of cardiovascular disease and cognitive decline: pregnancy and menopause. Biology of Sex Differences 2013 4:6.

\section{Submit your next manuscript to BioMed Central and take full advantage of:}

- Convenient online submission

- Thorough peer review

- No space constraints or color figure charges

- Immediate publication on acceptance

- Inclusion in PubMed, CAS, Scopus and Google Scholar

- Research which is freely available for redistribution 